Research Paper: Immunology

\title{
Antigen specific immune response in Chlamydia muridarum genital infection is dependent on murine microRNAs-155 and $-182$
}

\author{
Rishein Gupta ${ }^{1, *}$, Tanvi Arkatkar ${ }^{1, *}$, Jonathon Keck ${ }^{1}$, Gopala Krishna Lanka \\ Koundinya ${ }^{1}$, Kevin Castillo${ }^{1}$, Sabrina Hobel ${ }^{2}$, James P. Chambers ${ }^{1}$, Jieh-Juen Yu ${ }^{1}$, M. \\ Neal Guentzel ${ }^{1}$, Achim Aigner ${ }^{2}$, Lane K. Christenson ${ }^{3}$ and Bernard P. Arulanandam ${ }^{1}$ \\ ${ }^{1}$ South Texas Center for Emerging Infectious Diseases and Center of Excellence in Infection Genomics, University of Texas \\ at San Antonio, San Antonio, TX, USA \\ 2 Rudolf-Boehm-Institute for Pharmacology and Toxicology, Clinical Pharmacology, University of Leipzig, Härtelstraße, \\ Leipzig, Germany \\ ${ }^{3}$ Department of Molecular and Integrative Physiology, University of Kansas Medical Center, Kansas City, KS, USA \\ * These authors have contributed equally to this work \\ Correspondence to: Bernard P. Arulanandam, email: Bernard.Arulanandam@utsa.edu
}

Keywords: Chlamydia muridarum, host immunity, microRNA-155, microRNA-182, CD4+ T-cells, Immunology and Microbiology Section, Immune response, Immunity

Received: July 22, $2016 \quad$ Accepted: August 02, $2016 \quad$ Published: August 20, 2016

\section{ABSTRACT}

Anti-chlamydial immunity involves efficient presentation of antigens (Ag) to effector cells resulting in Ag-specific immune responses. There is limited information on inherent underlying mechanisms regulating these events. Previous studies from our laboratory have established that select microRNAs (miRs) function as molecular regulators of immunity in Chlamydia muridarum $(\mathrm{Cm})$ genital infection. In this report, we investigated immune cell type-specific miRs, i.e. miR-155 and -182 , and the role in Ag-specific immunity. We observed significant up-regulation of miR-155 in C57BL/6 bone marrow derived dendritic cells (BMDC), and miR-182 in splenic Ag-specific CD4+ T-cells. Using mimics and inhibitors, we determined that miR-155 contributed to BMDC activation following $\mathrm{Cm}$ infection. Co-cultures of miR-155 over-expressed in BMDC and miR-182 over-expressed in Ag-specific CD4+ ${ }^{+}$-cells, or miR-155/- BMDC with miR-182 inhibitor treated Ag-specific CD4 ${ }^{+} \mathrm{T}$-cells, resulted in IFN-Y production comparable to Ag-specific CD4 ${ }^{+} \mathrm{T}$-cells isolated from $\mathrm{Cm}$ infected mice. Additionally, miR-182 was significantly up-regulated in intranasally vaccinated mice protected against $\mathbf{C m}$ infection. In vivo depletion of miR-182 resulted in reduction in Ag-specific IFN-Y and genital pathology in $\mathrm{Cm}$ infected mice. To the best of our knowledge, this is the first study to report an interaction of miR-155 (in Cm infected DC) and miR-182 (in CD4+ $\mathrm{T}$-cell) resulting in Ag specific immune responses against genital $\mathbf{C m}$.

\section{INTRODUCTION}

The anti-Chlamydia trachomatis $(\mathrm{Ct})$ immune response involves neutrophils, macrophages, and dendritic cells followed by antigen (Ag)-specific and non-specific T-cells homing to the infected genital tract [1]. Critical interactions of infected mucosal epithelial cells and Ag-specific interferon (IFN)- $\gamma$ producing $\mathrm{CD}^{+}{ }^{+}$-cells results in effective anti-Ct immunity [2]. Despite efforts to determine anti-Ct immunity for effective vaccination strategies [3], Ct remains the leading sexually transmitted infection (STI) globally [4], and the most common STI in the US [5]. In infected women, chronic infection or exaggerated immune responses may potentially result in inflammatory pathology in the uterus and fallopian tube, and subsequently pelvic inflammatory disease (PID), and infertility [6]. Given that several laboratories [3, 4, 7-9] including ours [10], have reported that effective anti-Ct vaccination strategies require the targeted induction of adaptive immune responses, focused investigation on the role of underlying molecular modulators that have the ability to regulate $\mathrm{Ag}$-specific immunity is essential and timely.

To this end, we have reported on the role of 
microRNAs (miRs) as molecular regulators, in the genital tract of C. muridarum $(\mathrm{Cm}$, murine strain of genital $\mathrm{Ct}$ ) infected mice [11]. MicroRNAs are short, noncoding RNA species that post-transcriptionally regulate gene expression by binding to target gene mRNA to decrease translation and increase mRNA degradation [12]. Functionally, miRs have been shown to alter host processes including immunity, inflammation, and reproduction [13-17]. In our initial report, we investigated the contribution of spatio-temporally regulated inflammation and immunopathology associated miRs in anti-Cm immunity in C57BL/6 mice at 6 or 12 days post infection [11]. Additionally, we have recently reported the regulation of intracellular adhesion molecule (ICAM)1 gene by miR-214 in Cm infected mice [18]. We found that miR-214 regulated $I C A M-1$ expression differentially in $\mathrm{Cm}$ infected wild type and IL-17A deficient mice and lead to significant differences in upper genital pathology [18] . In addition to our reports on the role of miRs in Cm associated immune response and pathogenesis [11], the growing importance of investigating miRs in Ct infection has been emphasized [19]. Importantly, Igeitseme et al., have demonstrated the role of caspase-mediated cleavage inactivation of DICER, the miR biogenesis enzyme, and contribution of selected miRs in mesenchymal-epithelial transition and development of genital pathology in $\mathrm{Ct}$ serovar D infected mice [20], [21]. The association of single miR nucleotide polymorphisms and inflammatory genes in $\mathrm{Ct}$ infected humans [22], and the potential of miRs as biomarkers for genital $\mathrm{Ct}$ has been reported [23].

Anti-Ct immunity in vivo results from a complex of various immune cell types including Ag-presenting cells (APC) and CD4+ T-cells [4]. However, the contribution of miRs in initiating or regulating these processes in $\mathrm{Ct}$ infection has been not investigated. In the current study, we elucidated the contribution of specific miRs from two immune cell populations, dendritic (DC) and $\mathrm{CD}^{+}$ T-cells (highly effective Ag-presenting cells and the principle effector cells, respectively) involved in anti-Cm immunity [3, 24, 25]. We observed miR-155 and -182 to be significantly up-regulated in $\mathrm{Cm}$ infected cultured murine DC, and in Ag-specific murine $\mathrm{CD}^{+}$T-cells isolated at day 12 post infection, respectively. Activation of bone marrow derived DC (BMDC) as assessed by major histocompatibility complex II expression was regulated by miR-155. Co-culture of miR-155 treated BMDC (transfected with a miR-155 inhibitor) or miR$155^{-/}$BMDC with Ag-specific CD4 ${ }^{+}$T-cells resulted in significant up-regulation of IFN- $\gamma$ production. Ag-specific IFN- $\gamma$ production was abrogated in total splenocytes from miR-182 inhibitor treated mice compared to scramble treated or mock treated $\mathrm{Cm}$ infected mice. Moreover, following $\mathrm{Cm}$ infection, miR-182 inhibitor treated mice displayed significant reduction in development of upper genital pathology compared to scramble or mock treated mice. Importantly, IFN- $\gamma$ production in miR-155 mimic treated BMDC co-cultured with miR-182 mimic treated Ag-specific CD4 ${ }^{+}$T-cells was comparable to untransfected co-cultures. Untransfected co-cultures surrogately demonstrated/ mimicked the specific role of miR-155 and -182 in IFN- $\gamma$ production during an in vivo $\mathrm{Cm}$ infection. These findings were further corroborated by comparable IFN- $\gamma$ production in miR-155/- BMDC cocultured with $\mathrm{CD}^{+}$T-cells from miR-182 inhibitor treated mice compared to WT BMDC co-cultured with $\mathrm{CD}^{+} \mathrm{T}$-cells from $\mathrm{Cm}$ infected mice. Taken together, these results strongly demonstrate the combined effect of $2 \mathrm{miRs}$ (one up-regulated in the $\mathrm{BMDC}$, and the other in $\mathrm{CD}^{+}$ T-cells) in contributing to anti-Cm immune responses and IFN- $\gamma$ production reported previously to be critical for protection against a genital $\mathrm{Cm}$ infection $[1,4]$. To the best of our knowledge, this is the first report describing regulation of IFN- $\gamma$ production via miR-155 and -182 in $\mathrm{Cm}$ infected cells suggesting a role for these miRs in adaptive immunity following infection.

\section{RESULTS}

\section{Murine miR-155 is significantly up-regulated and contributes to activation of dendritic cells following Chlamydia muridarum infection}

Previously, we reported the spatio-temporal regulation of miRs in the genital tract of intravaginally infected C57BL/6 mice at 6 and 12 days post $\mathrm{Cm}$ infection [11]. We have demonstrated that miR-mediated modulation of host immunity in the genital tract (i.e., miR-214 regulates $I C A M-1)$ contributes to upper genital pathology in $\mathrm{Cm}$ infected mice [18]. In the current study, we investigated miRs in specific cell types critically needed in generation of anti-Cm immunity $[1,3,26$, 27]. Quantitative reverse transcriptase (qRT) was used to identify miRs in $\mathrm{Cm}$ infected BMDC. Using an array spotted with 88 miRs having immune-pathological regulatory function(s) (Figure 1a) [11], we observed 9 miRs up-regulated (red dots Figure 1b), and 3 miRs downregulated (green dots Figure $1 \mathrm{~b}$ ) to be physiologically regulated ( \pm 2-fold change) in $\mathrm{Cm}$ infected BMDC at $24 \mathrm{~h}$ post infection (Figure 1d, Supplementary Table 1). Importantly, the scatterplot (Figure 1b) and heat map profile (Figure 1c) revealed that the remaining miRs i.e., 76 out of 88 (open dots Figure 1b) were regulated in similar fashion to that observed for mock infected BMDC. Therefore, we investigated the role of miR-155 for its well-characterized and extensively reported role(s) in initiating and regulating immune responses [28, 29]. MiR-specific PCR primers confirmed the array results indicating significant up-regulation of miR-155 following $\mathrm{Cm}$ infection in BMDC (Figure 1d).

DCs are professional Ag-presenting cells (APC) 
that upon activation, initiate adaptive immune responses [26]. MiR-155 regulates DC activation and subsequent T-cell function $[30,31]$. Using flow cytometry, we next determined the number of activated cells in miR-155 treated, $\mathrm{Cm}$ infected BMDC cultures. A significant increase in the number of CD11 $\mathrm{c}^{+} \mathrm{MHC}-\mathrm{II}^{+}$expressing cells
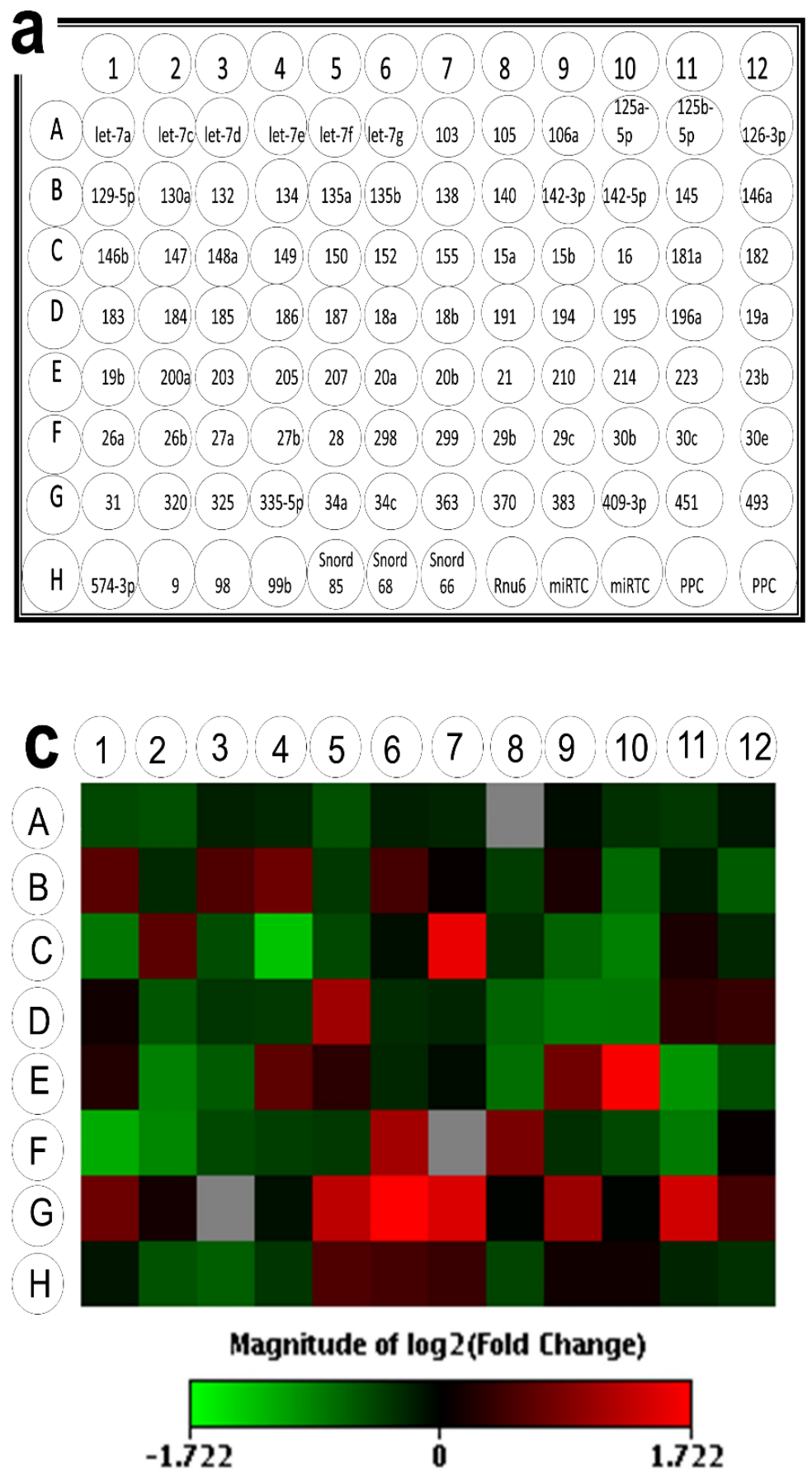
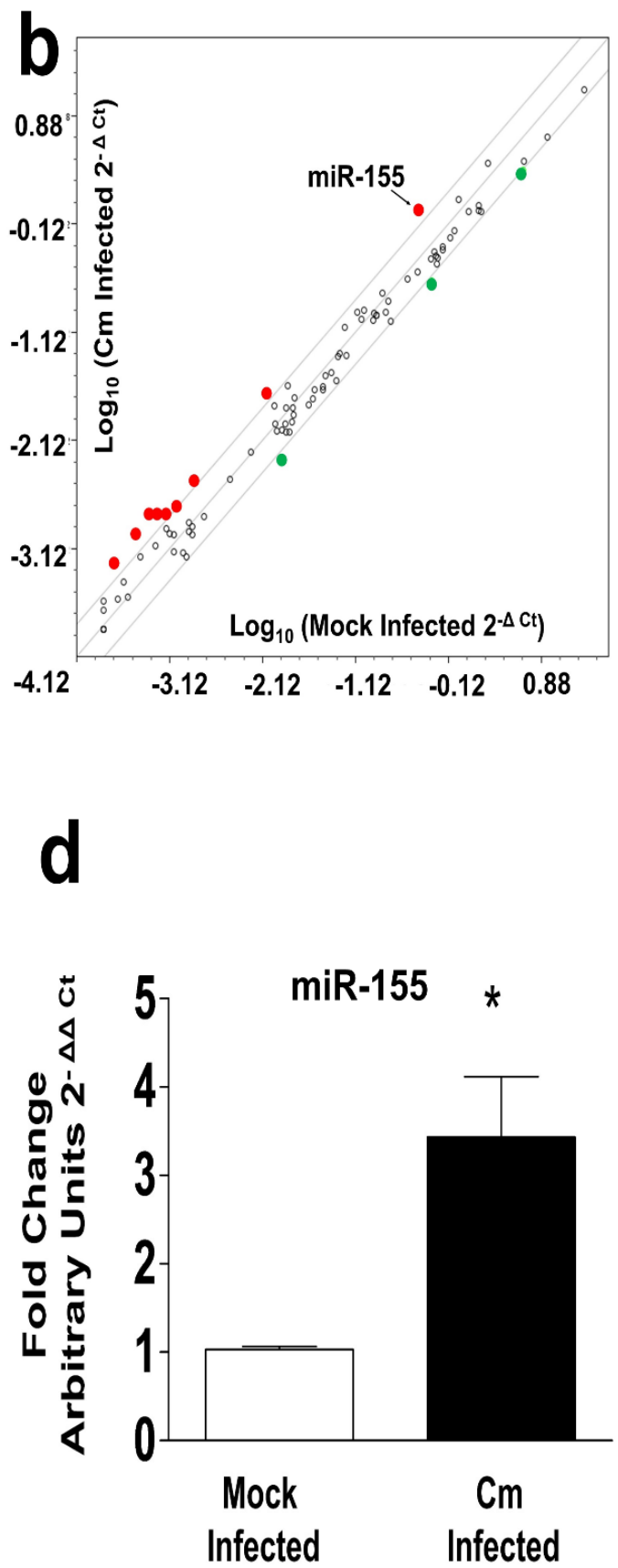

Figure 1: Murine miR-155 is significantly up-regulated in Chlamydia muridarum infected dendritic cells. Female C57BL/6 mouse bone marrow derived dendritic cells (BMDC) were infected with Chlamydia muridarum $(\mathrm{Cm}, \mathrm{MOI}=1)$. a. 'Inflammation and Immunopathology' focused RT2 miRNA plates were procured from Qiagen, Valencia, CA) - b. Scatterplot analyses (individual miRs represented by red and green dots as up- or down-regulated respectively ( \pm 2 -fold change) and open dots $(< \pm 2$-fold change) in Cm infected BMDC compared to mock infected BMDC. c. heat map profiles of miRs in RT2 miRNA plates were plotted by comparing miR profiles of $\mathrm{Cm}$ infected and mock infected BMDC d. MiR-155 specific PCR amplication revealed significant up-regulation compared to mock controls. Results are representative of 3 independent experiments. ${ }^{*} P<0.05$ Student's $t$ test; black arrow indicates miR-155. Rnu6 and Snord 68 were used as housekeeping miRs. MOI = Multiplicity of infection; $\mathrm{miR}=$ microRNA. 
(\%) in Cm infected BMDC compared to mock infection was observed (Figure 2a). In order to demonstrate 'cause and effect' $\mathrm{MHC}-\mathrm{II}^{+}$expression was determined in $\mathrm{CD}_{11 \mathrm{c}^{+}}$ BMDC transfected with miR-155 mimics or inhibitors. The percent of $\mathrm{CD} 11 \mathrm{c}^{+} \mathrm{MHC}-\mathrm{II}^{+}$cells was significantly decreased in $\mathrm{Cm}$ infected, miR-155 inhibitor transfected BMDC cells compared to $\mathrm{Cm}$ infected, untransfected cells (Figure $2 \mathrm{a}$ ). In contrast, $\mathrm{CD} 11 \mathrm{c}^{+} \mathrm{MHC}-\mathrm{II}^{+}$cells were significantly increased in $\mathrm{Cm}$ infected, miR-155 mimic transfected BMDC cells compared to $\mathrm{Cm}$ infected, miR-
155 inhibitor transfected cells (Figure 2a). Transfection with miR-155 inhibitors that down-regulate endogenous

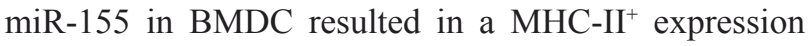
change that was significantly reduced compared to miR155 mimic transfected cells when endogenous miR155 was overexpressed (Figure 2b). In contrast, BMDC transfected with controls, i.e., scrambled-miRs exhibited significantly lesser MHC-II+ expression change compared to untransfected and mimic transfected cells (Figure 2b). We observed no significant contribution of miR-155 in

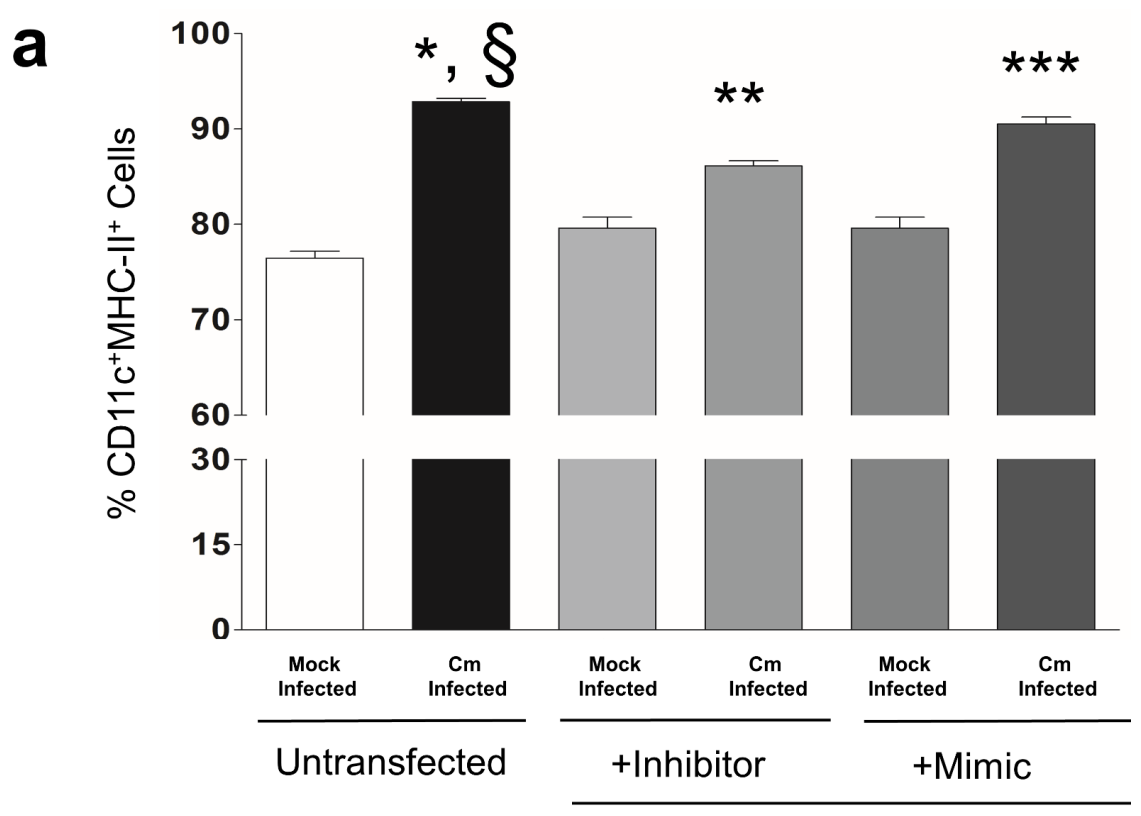

b

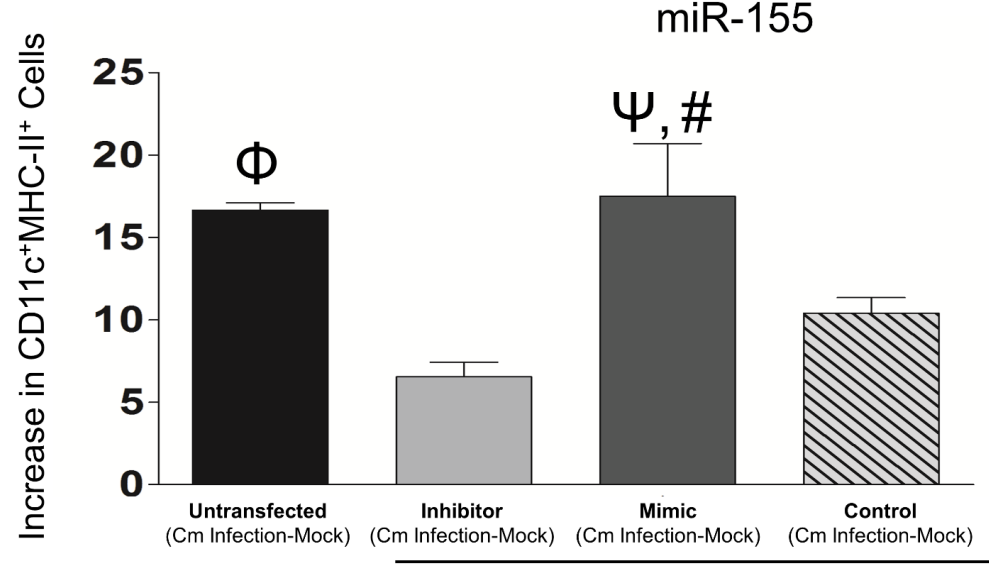

miR-155

Figure 2: Murine miR-155 regulates expression of Major Histocompatibility Complex II (MHC-II) in Chlamydia muridarum infected dendritic cells. BMDC were pulsed with $\mathrm{Cm}(\mathrm{MOI}=1)$ and $24 \mathrm{hrs}$ later MHC-II expression was determined in $\mathrm{CD} 11 \mathrm{c}^{+} \mathrm{BMDC}$ using flow cytometry. a. Frequency of $\mathrm{CD} 11 \mathrm{c}^{+} \mathrm{MHCII}^{+}$cells was plotted as $\%$ of total cells in $\mathrm{Cm}$ or mock infected untransfected, miR-155 inhibitor or mimic transfected BMDC. Results are representative of 2 independent experiments. $P<0.05$ using ANOVA with Bonferroni's Multiple Comparison Test. ${ }^{*} \mathrm{Cm}$ infected animals compared to mock infected; ${ }^{\S} \mathrm{Cm}$ infected, untransfected compared to Cm infected, miR-155 inhibitor transfected; $* * \mathrm{Cm}$ infected compared to mock control infected, miR-155 inhibitor transfected; $* * * \mathrm{Cm}$ infected miR-155 mimic compared to Cm infected, miR-155 inhibitor transfected BMDC. b. Increase in frequency of CD11 ${ }^{+} \mathrm{MHCII}{ }^{+}$cells following $\mathrm{Cm}$ infection relative to respective mock control infection in untransfected, or miR-155 inhibitor, mimic or control (scramble mimic) was determined. Results are representative of 3 independent experiments. $P<0.05$ using ANOVA with Bonferroni Multiple Comparison Test*. ${ }^{\Phi} \mathrm{Cm}$ infected-mock wells in un-transfected wells compared to miR-155 inhibitor wells. ${ }^{\Psi} \mathrm{Cm}$ infected mimic compared to miR-155 inhibitor transfected wells. "miR-155 mimic transfected compared to miR-155 control transfected wells. 
regulating expression levels of CD40, CD80, and CD86 in $\mathrm{Cm}$ infected BMDC (data not shown). Isotype controls for all experimental conditions detected low positivity in $\mathrm{CD} 11 \mathrm{c}^{+} \mathrm{MHC}-\mathrm{II}^{+}$expressing cells (data not shown). Collectively, these results demonstrate that miR-155 contributes to $\mathrm{MHC}-\mathrm{II}$ expression in $\mathrm{CD} 11 \mathrm{c}^{+} \mathrm{BMDC}$ following $\mathrm{Cm}$ infection.

\section{Murine miR-155 in Chlamydia muridarum infected dendritic cells regulates interferon- $\gamma$ production}

Given the potential of miR-155 regulation of adaptive immunity [28, 32], we investigated the role of miR-155 in mediating Cm-specific immune responses. We co-cultured miR-155 inhibitor or mimic transfected
BMDC or miR-155\% or WT BMDC with splenic CD4 ${ }^{+}$ $\mathrm{T}$ cells isolated at day 12 from mock or $\mathrm{Cm}$ infected mice and measured IFN- $\gamma$ production by ELISA (Figure $3 \mathrm{a}, 3 \mathrm{c}$ ). We observed a significant increase in IFN- $\gamma$ production in $\mathrm{Cm}$ infected BMDC co-cultured with $\mathrm{Cm}$ infected $\mathrm{CD}^{+} \mathrm{T}$ cells, i.e., splenic $\mathrm{CD}^{+} \mathrm{T}$ cells isolated at day 12 from $\mathrm{Cm}$ infected mice compared to mock infected BMDC (Figure 3b). Importantly, a significant increase in IFN- $\gamma$ production in $\mathrm{Cm}$ infected, miR-155 inhibitor transfected BMDC co-cultured with $\mathrm{Cm}$ infected $\mathrm{CD}^{+} \mathrm{T}$ cells compared to $\mathrm{Cm}$ infected, miR-155 mimic transfected BMDC was observed demonstrating a 'cause and effect' relationship between miR-155 manipulated DC, and production of IFN- $\gamma$ when co-cultured with Ag-specific $\mathrm{CD}^{+} \mathrm{T}$ cells (Figure 3b). Additionally, the observed interactions between miR-155 in BMDC, and production of IFN- $\gamma$ was detected specifically upon co-culture with
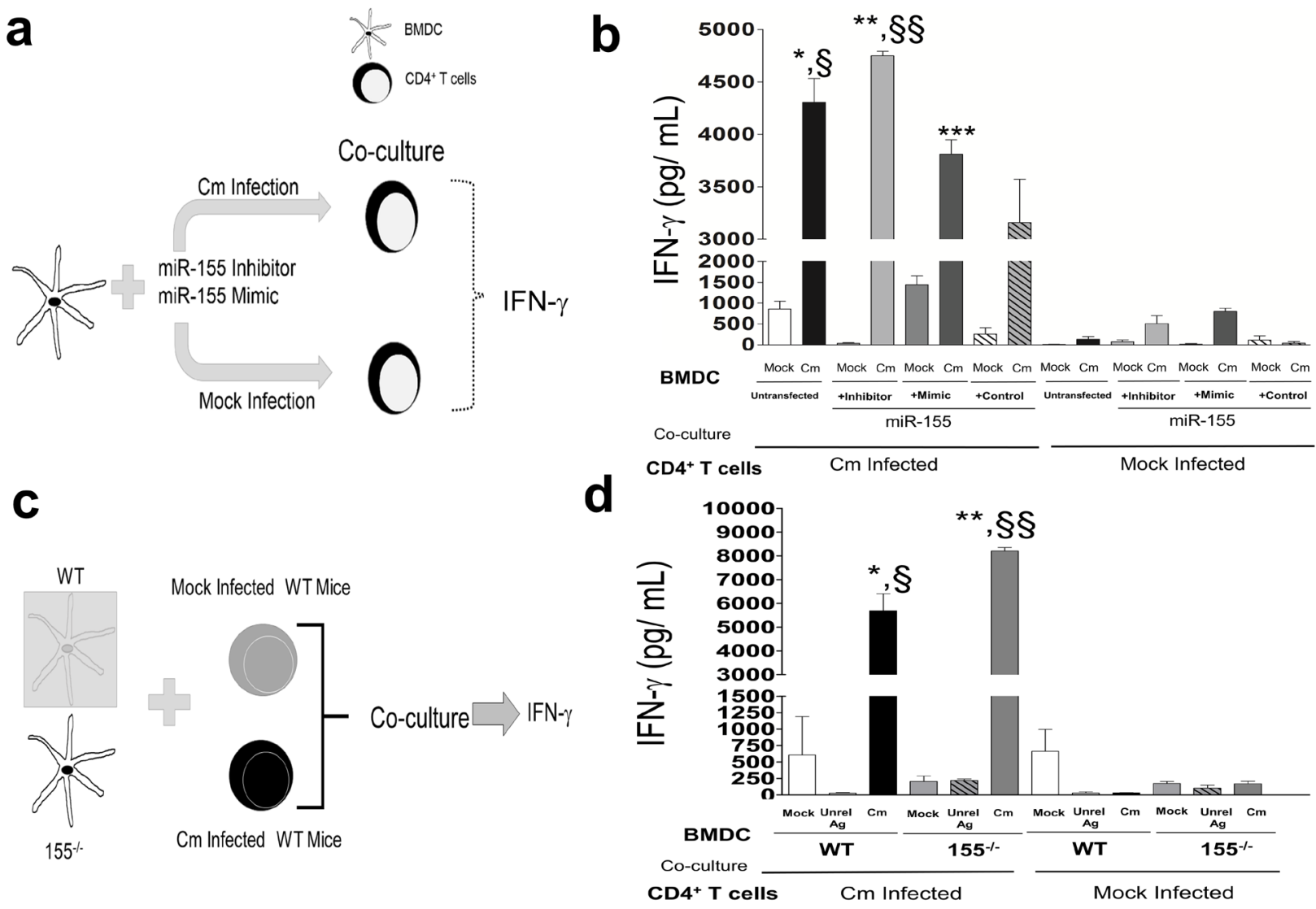

Figure 3: Murine miR-155 in Chlamydia muridarum infected dendritic cells regulates interferon- $\gamma$ production in an antigen specific manner. a. Diagrammatic representation of BMDC pulsed with $\mathrm{Cm}(\mathrm{MOI}=1)$ and co-cultured $24 \mathrm{~h}$ later with splenic $\mathrm{CD} 4^{+} \mathrm{T}$ cells isolated at day 12 from mock and $\mathrm{Cm}$ infected mice $(n=3) ; \mathbf{b}$. IFN- $\gamma$ production $72 \mathrm{~h}$ post co-culture was determined. $P<0.05$ using ANOVA with Bonferroni's Multiple Comparison Test. ${ }^{*} \mathrm{Cm}$ infected, untransfected BMDC compared to mock infected, untransfected BMDC. ${ }^{* *} \mathrm{Cm}$ infected, miR-155 inhibitor BMDC compared to mock infected control, miR-155 inhibitor BMDC. ${ }^{* * *} \mathrm{Cm}$ infected, miR155 mimic BMDC compared to mock infected control, miR-155 mimic BMDC. §Cm infected, untransfected BMDC compared to Cm infected, control transfected (AllStar Negative Control siRNA, Qiagen) BMDC. ${ }^{\S} \mathrm{Cm}$ infected, miR-155 inhibitor transfected BMDC compared to Cm infected, miR-155 mimic transfected BMDC. Results are representative of 2 independent experiments. c. WT and miR$155^{-/} \mathrm{BMDC}$ were pulsed with mock, $\mathrm{Cm}(\mathrm{MOI}=1)$ or unrelated antigen and co-cultured $24 \mathrm{~h}$ later with splenic $\mathrm{CD} 4^{+} \mathrm{T}$ cells isolated at day 12 from mock and $\mathrm{Cm}$ infected mice $(n=3)$, d. IFN- $\gamma$ production $72 \mathrm{~h}$ post co-culture was determined. $P<0.05$ using ANOVA with Bonferroni's Multiple Comparison Test. Results are representative of 2 independent experiments. 
$\mathrm{CD}^{+} \mathrm{T}$ cells isolated from $\mathrm{Cm}$ infected mice compared to mock infected mice (Figure $3 \mathrm{~b}$ ). We corroborated our results in WT BMDC manipulated with miR-155 mimics and inhibitors (Figure 3a, 3b) by comparing production

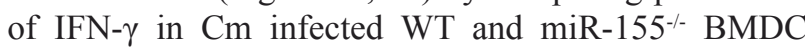
(Figure 3c, 3d). Similar to responses in Figure 3b, we observed a significant increase in IFN- $\gamma$ production in Cm infected $155^{--}$BMDC compared to WT BMDC upon co-culture with $\mathrm{Cm}$ infected $\mathrm{CD}^{+} \mathrm{T}$ cells (Figure $3 \mathrm{~d}$ ). Taken together, these results demonstrate that miR-155 in BMDC affects Th1 clonal expansion and specifically, IFN- $\gamma$ production following interactions with $\mathrm{Cm}$-infected CD4+ T cells.
MiR-182 is significantly regulated in $\mathrm{CD4}^{+} \mathrm{T}$ cells from Chlamydia muridarum infected or vaccinated mice and contributes to Ag-specific immune response in vivo

Efficient Ag presentation by DC results in clonal proliferation of effector T-cell populations for generation of anti-Cm immunity [1, 26]. Using qRT-PCR, we measured expression of $\mathrm{FOXO}-1$, a forkhead transcription factor expressed in resting T-cells and a suppressor of proliferation to functional T-cells [33]. We observed significant down-regulation of $\mathrm{FOXO}-1$ in splenic $\mathrm{CD}^{+} \mathrm{T}$ cells isolated at day 12 from $\mathrm{Cm}$ infected mice compared
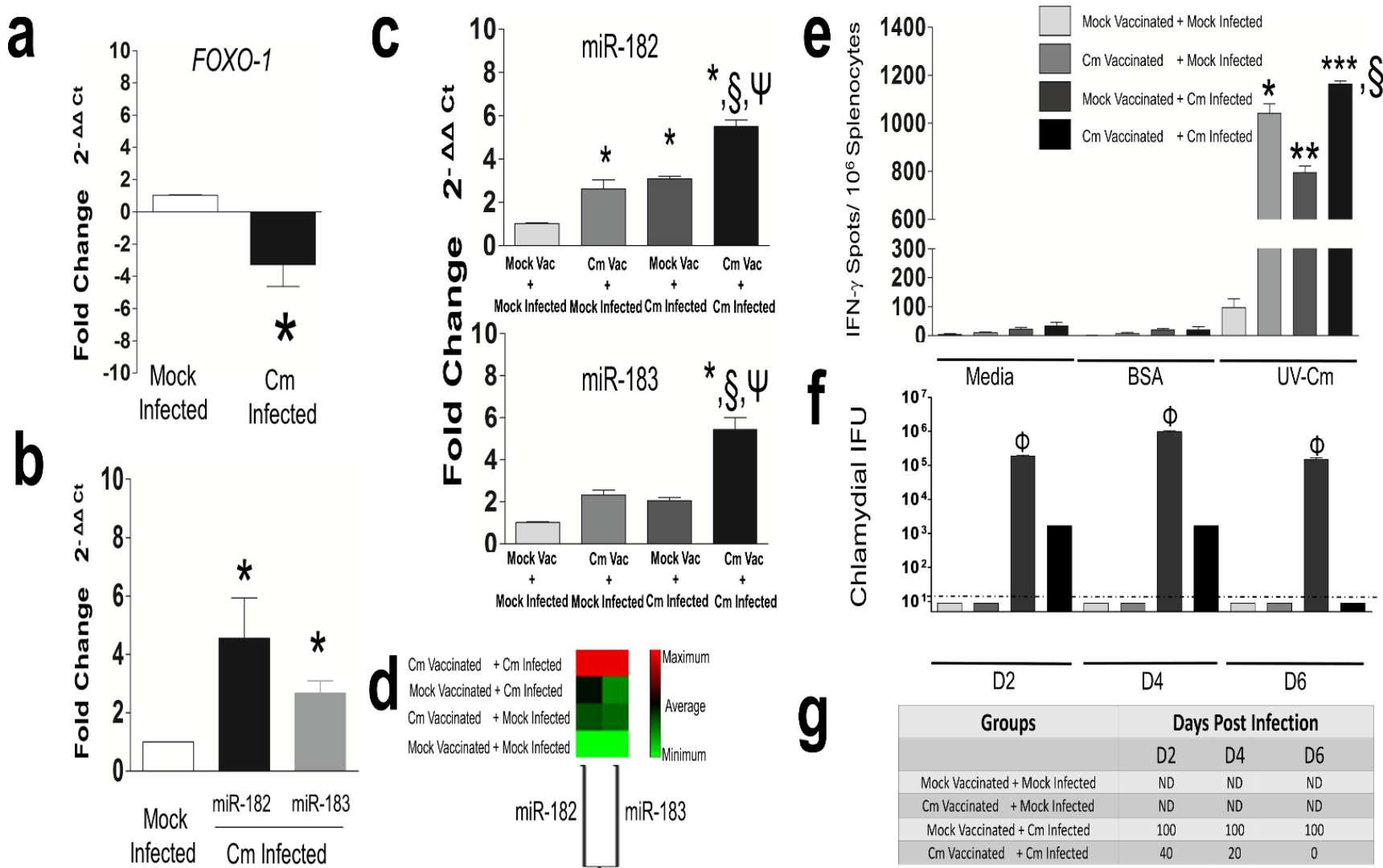

Figure 4: Murine FOXO-1 and miR-182 is significantly regulated in Chlamydia muridarum infected $\mathrm{CD4}^{+} \mathrm{T}$ cells. C57BL/6 mice $(n=3)$ were challenged intravaginally with $5 \times 10^{4} \mathrm{IFU} \mathrm{Cm}$. Splenocytes were collected at day 12 post infection and CD4 ${ }^{+} \mathrm{T}$ cells purified. Real time PCR was performed for murine a. FOXO-1; and b. miR-182 and -183. Results are representative of 3 (FOXO-1) and 4 (miR-182 and-183) independent experiments. ${ }^{*} P<0.05$ Student's $t$ test compared to mock control infected mice. GAPDH or Snord 68 and 85 used as housekeeping gene or miRs, respectively. c. C57BL/6 mice ( $n=5 /$ group) were vaccinated intranasally with $500 \mathrm{IFU} \mathrm{Cm}$ or PBS (mock), rested for a month and subsequent intravaginal infection with $5 \times 10^{4} \mathrm{IFU} \mathrm{Cm}$ or PBS (mock). Splenic CD4 ${ }^{+} \mathrm{T}$ cells were purified at day 6 post infection and miR-182 and -183 expression was assessed. Results are representative of 2 independent experiments. $P<0.05$ using ANOVA with Tukey-B * compared to mock vaccinated + mock infected mice. ${ }^{\S} \mathrm{Cm}$ vaccinated $+\mathrm{Cm}$ infected compared to $\mathrm{Cm}$ vaccinated + mock Infected. ${ }^{\Psi} \mathrm{Cm}$ vaccinated $+\mathrm{Cm}$ infected compared to mock vaccinated $+\mathrm{Cm}$ Infected mice. d. Non-supervised hierarchical clustergram depicting miR-182 and -183 co-regulation in vaccinated and infected groups. e. ELISPOT revealed significant increase in antigen-specific IFN- $\gamma / 10^{6}$ splenocytes in $\mathrm{Cm}$ vaccinated $+\mathrm{Cm}$ infected compared to other groups at day 6 post $\mathrm{Cm}$ infection. $P$ $<0.05$ using ANOVA with Tukey-B $P<0.05^{*, * * * * * *}$ compared to mock vaccinated + mock infected mice. ${ }^{\S} \mathrm{Cm}$ vaccinated $+\mathrm{Cm}$ infected compared to $\mathrm{Cm}$ vaccinated + mock infected control. f. Bacterial shedding; g. Percent mice positive for $\mathrm{Cm}$ in all groups ( $n=5 /$ group $)$ was monitored and robust protection was observed in $\mathrm{Cm}$ vaccinated $+\mathrm{Cm}$ infected compared to mock vaccinated $+\mathrm{Cm}$ infected mice $(P<0.05$ $=\Phi) . \mathrm{ND}=$ Not detected. Dotted line indicates below the level of detection. 
to mock infected animals (Figure 4a). We next, determined expression of miR-182 previously reported to regulate FOXO-1 expression [34, 35]. MiR-182 was observed to be significantly up-regulated in day $12 \mathrm{CD}^{+} \mathrm{T}$ cells from $\mathrm{Cm}$ infected mice compared to mock infected animals (Figure 4 b) demonstrating an inverse correlation between miR182 and $F O X O-1$ expression in $\mathrm{CD}^{+}{ }^{+} \mathrm{T}$ cells.

We further hypothesized that miR-182 regulation in Ag-specific $\mathrm{CD}^{+} \mathrm{T}$ cells (i.e., the primary effector cells during the adaptive immune phase of a genital $\mathrm{Cm}$ infection [27]) might potentially be involved in protection against a subsequent genital $\mathrm{Cm}$ infection. Therefore, we vaccinated (intranasally) groups of mice with $\mathrm{Cm}$ and after resting, subsequently infected intravaginally with $\mathrm{Cm}$. We observed significant up-regulation of miR-182 in day 6 splenic $\mathrm{CD}^{+} \mathrm{T}$ cells from $\mathrm{Cm}$ vaccinated $+\mathrm{Cm}$ infected mice compared to mock vaccinated + mock infected animals (Figure 4c). MiR-182 expression was also observed to be significantly up-regulated in $\mathrm{Cm}$ vaccinated $+\mathrm{Cm}$ infected mice compared to mock vaccinated + $\mathrm{Cm}$ infected mice or $\mathrm{Cm}$ vaccinated + mock infected animals (Figure 4c). Additionally miR-183 (a member of the miR-182 family [35]) was found to be significantly up-regulated in day $12 \mathrm{CD} 4+\mathrm{T}$ cells from $\mathrm{Cm}$ infected mice (Figure $4 \mathrm{~b}$ ), and in $\mathrm{Cm}$ vaccinated $+\mathrm{Cm}$ infected mice (Figure 4c) compared to control. Importantly, similar heat intensity profiles (light to dark) of a nonsupervised hierarchical clustergram were indicative of probable co-regulation and expression of miR-182 and -183 in vaccinated mice; thereby, suggesting similar roles for both miRs in Ag-specific immune responses (Figure 4d). Expression of miR-182 correlated with protection against subsequent $\mathrm{Cm}$ infection at day 6 post infection as determined by production of Ag-specific IFN- $\gamma$ ( determined by ELISPOT) (Figure 4e), and resolution of infection (Figure 4f) from all mice (Figure $4 \mathrm{~g}$ ) in $\mathrm{Cm}$ vaccinated $+\mathrm{Cm}$ infection compared to control groups. Taken together, regulation of miR-182 in Ag-specific $\mathrm{CD}^{+} \mathrm{T}$ cells from $\mathrm{Cm}$ infected and vaccinated mice suggests its contribution to generation of Ag-specific immune responses and protective immunity.

Given that miR-182 was up-regulated in Ag-specific $\mathrm{CD}^{+} \mathrm{T}$ cells from $\mathrm{Cm}$ infected and vaccinated mice, we determined the in vivo relevance of miR-182 in genital $\mathrm{Cm}$ infection. We used a depletion regimen for up to day 80 post infection (Figure 5a) which had no differential effect on weight change (Figure 5b), obvious health and wellness of mice and as expected, lead to significant reduction in miR-182 expression in genital tract (Figure 5c) or splenic $\mathrm{CD}^{+} \mathrm{T}$ cells (Figure 5d) isolated from miR-182 inhibitor treated mice following $\mathrm{Cm}$ infection compared to $\mathrm{Cm}$ infected mice at the assessed time points. We observed significant reduction in Ag-specific IFN- $\gamma$ levels in splenocytes isolated from miR-182 inhibitor treated mice compared to $\mathrm{Cm}$ infected mice or scramble treated mice at day 12 post infection (Figure 5e). While comparable bacterial shedding profiles between mock-treated, scramble- or miR-182 inhibitor treated $\mathrm{Cm}$ infected mice over a 30 day post infection period using culture (Figure $5 \mathrm{f}$ ) or $16 \mathrm{~s}$ PCR (at indicated time points, namely days 6 , 12 and 80 post infection, Figure $5 \mathrm{~g}$ ) were observed, we found significant reduction in oviduct pathology (Figure 5h) and total cellular infiltrates (Figure 5i) in miR-182 inhibitor treated mice compared to $\mathrm{Cm}$ infected mice or scramble treated mice. Mock infected and $\mathrm{Cm}$ infected mice with vehicle alone treatment displayed immune profiles, shedding and genital pathology comparable to mock infected and $\mathrm{Cm}$ infected mice respectively (data not shown). Additionally, despite miR-183 being co-regulated with miR-182 (Figure 4d), miR-182 inhibitor failed to significantly downregulate miR-183 expression in day 12 splenic $\mathrm{CD}^{+} \mathrm{T}$ cells thereby indicating the specificity of the depletion regime for miR-182. Importantly, while Agspecific IFN- $\gamma$ levels are critical for clearance of $\mathrm{Cm}$ from mice, it also leads to collateral damage to genital tissue architecture and development of upper genital pathology. Taken together our results (Figures 4-5) demonstrate that miR-182 upregulated in Ag-specific $\mathrm{CD}^{+} \mathrm{T}$ cells directly contributes to Ag-specific IFN- $\gamma$ and $\mathrm{Cm}$ infected associated disease pathogenesis in vivo.

\section{Interferon- $\gamma$ production in $C$. muridarum infected dendritic cells and $\mathrm{CD4}^{+} \mathrm{T}$ cells is co-regulated by miRs-155 and $\mathbf{- 1 8 2}$}

Since IFN- $\gamma$ is the key cytokine involved in adaptive immunity against $\mathrm{Cm}$ infection, and is produced by $\mathrm{Ag}$ specific $\mathrm{CD}^{+} \mathrm{T}$ cells from $\mathrm{Cm}$ infected or vaccinated mice [27], we determined the contribution of miR-182 in generation of Ag-specific IFN- $\gamma$. As previously indicated, cf. Figure $3 b$, we observed significant production of IFN- $\gamma$ in Cm infected, untransfected BMDC co-cultured with untransfected $\mathrm{CD}^{+} \mathrm{T}$ cells isolated at day 12 post infection from $\mathrm{Cm}$ infected mice (Figure 6a). Moreover, since miRs-155 and -182 were significantly up-regulated in BMDC (Figure 1) and $\mathrm{CD}^{+} \mathrm{T}$ cells (Figure 4) respectively, we also determined the effect of co-culturing miRs-155 and -182 treated cells. IFN- $\gamma$ levels were observed to be significantly increased in $\mathrm{Cm}$ infected, miR-155 mimic transfected BMDC when co-cultured with miR-182 mimic transfected, $\mathrm{CD}^{+} \mathrm{T}$ cells isolated from $\mathrm{Cm}$ infected mice compared to mock infected BMDC (Figure 6a). This increased IFN- $\gamma$ was comparable to untransfected co-cultures (Figure 6a).

In order to corroborate these findings, we utilized our in vivo depletion regimen (Figure 5a) and isolated splenic $\mathrm{CD}^{+} \mathrm{T}$ cells from mock treated, scramble treated and miR-182 inhibitor treated mice at day 12 post $\mathrm{Cm}$ infection. As shown in figure 6b, Ag-specific IFN- $\gamma$ levels were significantly reduced in $\mathrm{Cm}$ infected WT BMDC cocultured with $\mathrm{CD}^{+} \mathrm{T}$ cells from miR-182 inhibitor 
a

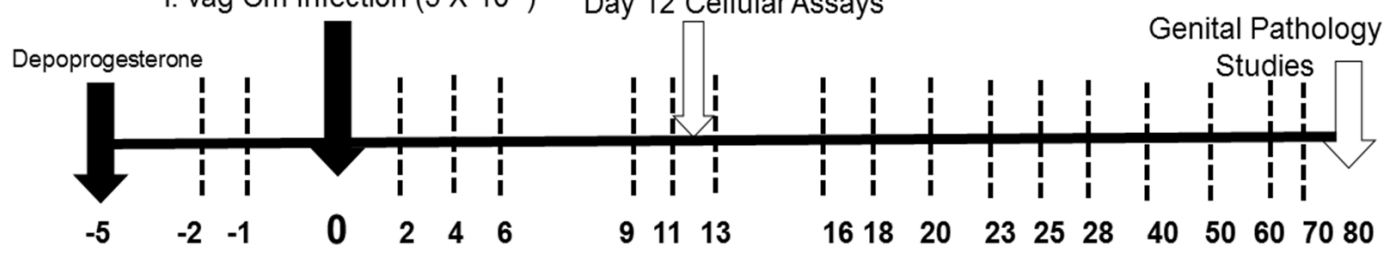

b
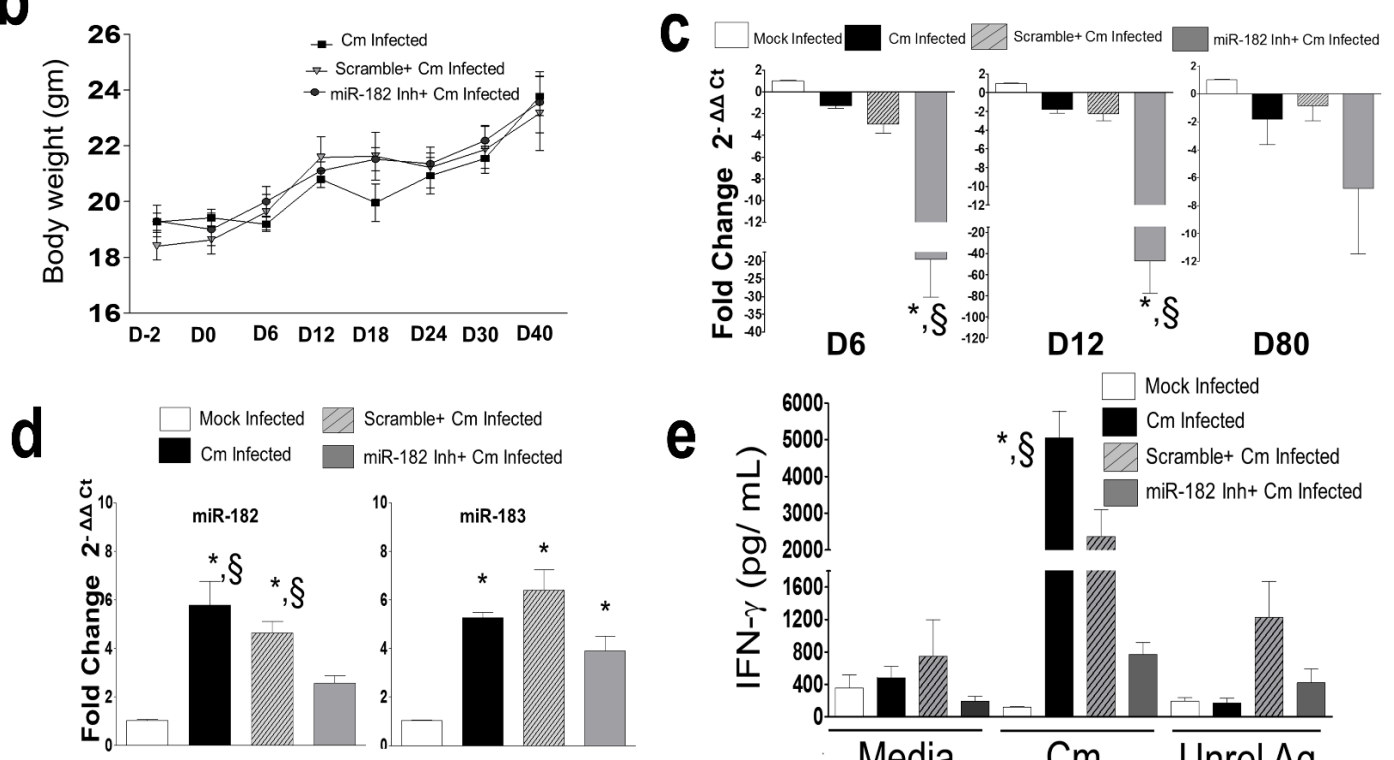

e
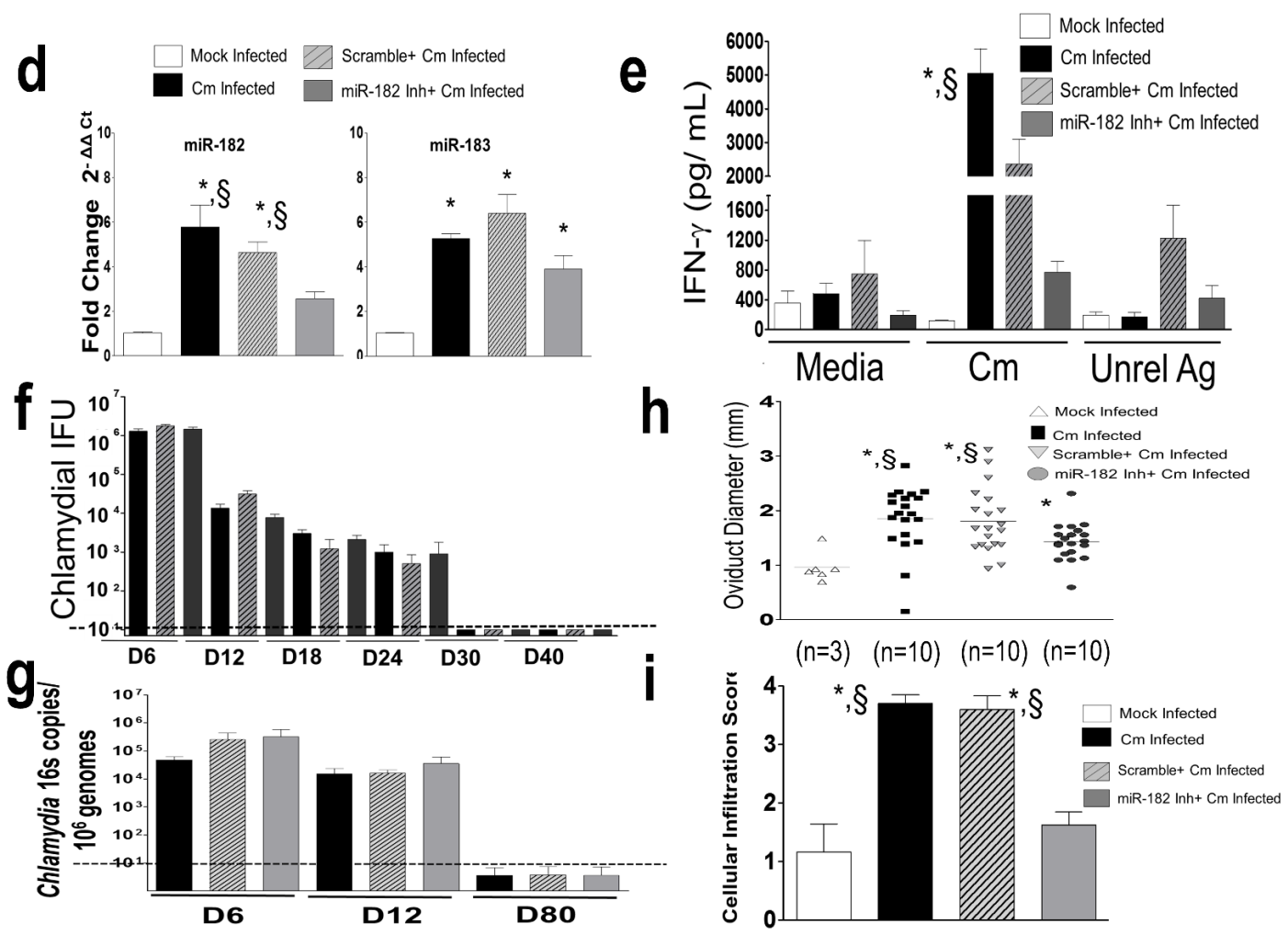

Figure 5: Murine miR-182 significantly regulates Ag-specific immune responses and disease pathology in Chlamydia muridarum infected mice. C57BL/6 mice ( $n=16 /$ group) were challenged intravaginally with $5 \times 10^{4} \mathrm{IFU} \mathrm{Cm}$. a. Using a i.p depletion regimen, miR-182 was depleted using miR-182 inhibitor or controls (scramble treated, mock treated) at each of the time points indicated by dashed lines $\mathbf{b}$. Monitoring of weight on indicated days revealed no significant changes due to treatment. $P<0.05$ using ANOVA with repeated measures. Significant regulation in miR-182 expression in $\mathbf{c}$. genital tract (down-regulation compared to mock) and d. splenic $\mathrm{CD} 4^{+} \mathrm{T}$ cells (up-regulation compared to mock) collected at indicated time points ( $n=3 /$ group/ time point) was observed. $P<0.05$ using ANOVA with Tukey B Comparison Test in c., * miR-182 inhibitor treated Cm infected mice compared to Cm infected mice; ${ }^{\S}$ miR- 182 inhibitor treated $\mathrm{Cm}$ infected mice compared to scramble treated $\mathrm{Cm}$ infected mice and $\mathbf{d}$. significant increase in miR-182 and miR-183 expression * compared to mock infected mice; ${ }^{\S}$ compared to miR-182 inhibitor treated $\mathrm{Cm}$ infected mice. e. Splenocytes $(n=3)$ were collected at day 12 post infection and IFN- $\gamma$ was measured $72 \mathrm{~h}$ post co-culture. Results are representative of 5 independent experiments. $P<0.05$ using ANOVA with Bonferroni's Multiple Comparison Test ${ }^{*} \mathrm{Cm}$ infected mice compared to mock infected mice. ${ }^{\S} \mathrm{Cm}$ infected mice compared to miR-182 inhibitor treated Cm infected mice. f. Bacterial shedding, g. tissue bacterial burden qPCR of Chlamydia 16s encoding gene (at indicated time points), h. oviduct pathology and i. total cellular infiltration were evaluated in all groups of mice. Each dot is representative of an oviduct. Results are representative of 2 independent experiments. Kruskall-Wallis test was used for comparing bacterial shedding profiles and histopathology. $P<0.05 *$ compared to mock infected mice. ${ }^{\S}$ compared to miR-182 inhibitor treated $\mathrm{Cm}$ infected mice. Dotted line indicates below the level of detection. 
treated mice compared to $\mathrm{Cm}$ infected mice. Importantly, this significant difference in IFN- $\gamma$ levels was 'lost/ rescued in' upon co-culture of $\mathrm{Cm}$ infected miR-155/BMDC with $\mathrm{CD}^{+} \mathrm{T}$ cells from miR-182 inhibitor treated

a

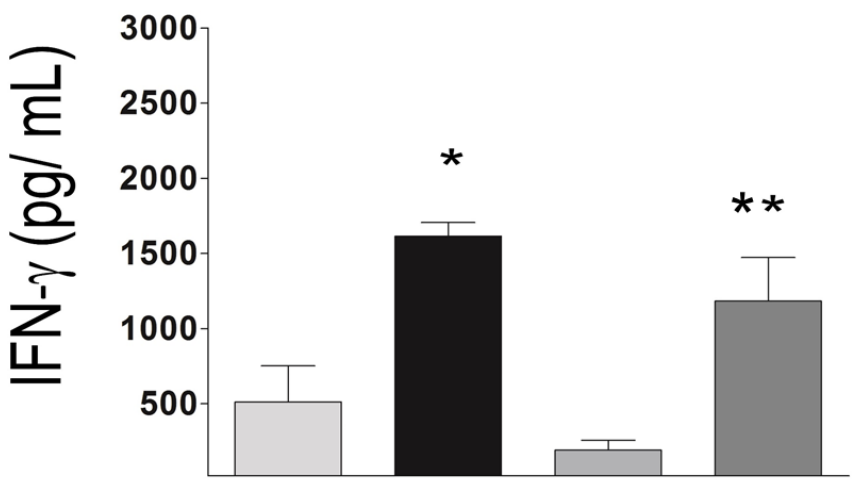

\begin{tabular}{|c|c|c|c|c|}
\hline BMDC & Mock & $\mathrm{Cm}$ & Mock & \\
\hline C- & & & + Mimic & miR-155 \\
\hline $\mathrm{CD4}^{+} \mathrm{T}$ cells & Untrans & cted & + Mimic & miR-182 \\
\hline & & $\mathrm{Cm}$ & ted & \\
\hline
\end{tabular}

b

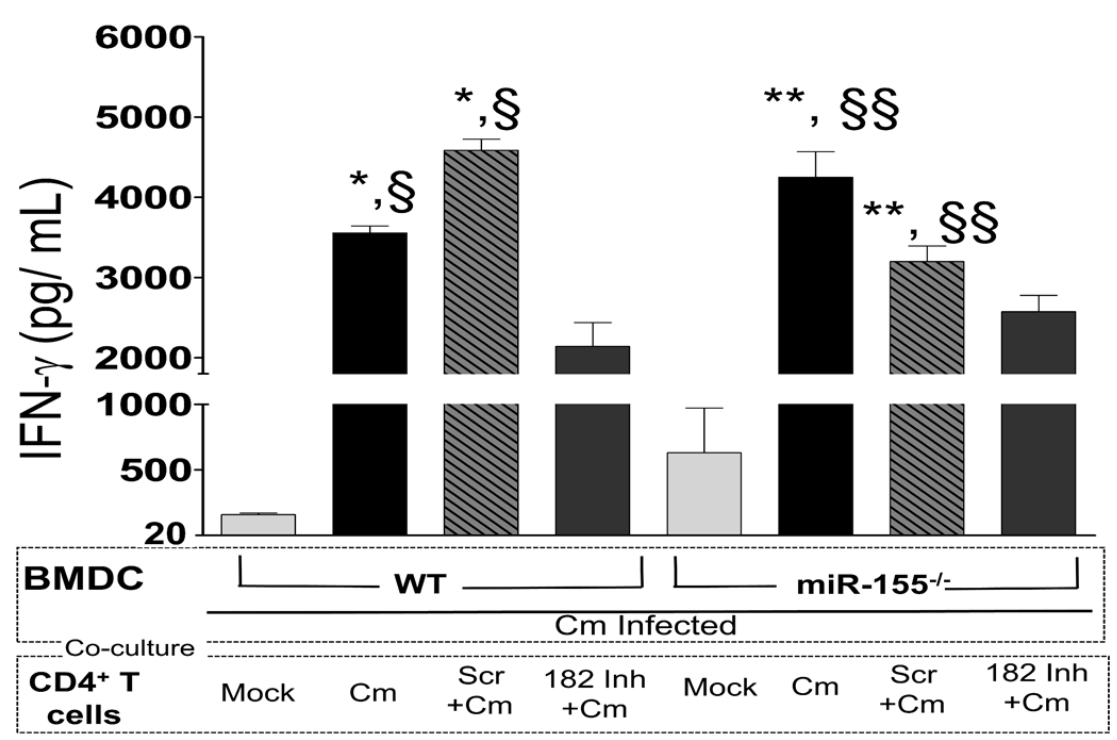

Figure 6: Interferon- $\gamma$ production in Chlamydia muridarum infected dendritic and $\mathrm{CD}^{+} \mathbf{T}$ cells is co-regulated by miR-155 and -182. a. C57BL/6 mice $(n=5)$ were challenged intravaginally with $5 \times 10^{4} \mathrm{IFU} \mathrm{Cm}$. Splenocytes were collected at day 12 post infection and $\mathrm{CD} 4^{+} \mathrm{T}$ cells purified. IFN- $\gamma$ was measured $72 \mathrm{~h}$ post co-culture in miR-155 mimic or untransfected BMDC mock or $\mathrm{Cm}$ infected $(\mathrm{MOI}=1)$ and at $24 \mathrm{~h}$ post-infection co-cultured with $\mathrm{CD} 4^{+} \mathrm{T}$ cells. Co-cultured $\mathrm{CD} 4^{+} \mathrm{T}$ cells were mock transfected or transfected with miR-182 mimic. $P<0.05$ using ANOVA with Tukey-B. ${ }^{*} \mathrm{Cm}$ infected, untransfected BMDC compared to mock infected, untransfected BMDC. ${ }^{* *}$ miR-182 mimic transfected CD4 ${ }^{*} \mathrm{~T}$ cells co-cultured with miR-155 mimic Cm infected BMDC compared to miR-182 mimic transfected $\mathrm{CD} 4+\mathrm{T}$ cells co-cultured with miR-155 mimic, mock infected BMDC. b. C57BL/6 mice $(n=3)$ were challenged intravaginally with $5 \times 10^{4} \mathrm{IFU} \mathrm{Cm}$. Groups of mice were depleted for miR-182 using regimen described in Figure 5a. Splenocytes were collected at day 12 post infection and CD4 ${ }^{+} \mathrm{T}$ cells purified. IFN- $\gamma$ was measured $72 \mathrm{~h}$ post co-culture in miR-155 and at $24 \mathrm{~h}$ post-infection co-cultured with CD $4^{+}$T cells. $P<0.05$ using ANOVA with Tukey-B. * compared to Cm infected WT BMDC cocultured with $\mathrm{CD} 4^{+} \mathrm{T}$ cells isolated from mock infected mice. ${ }^{\S}$ compared to $\mathrm{Cm}$ infected WT BMDC co-cultured with $\mathrm{CD} 4^{+} \mathrm{T}$ cells isolated from miR-182 inhibitor treated $\mathrm{Cm}$ infected mice. ** compared to $\mathrm{Cm}$ infected miR-155 ${ }^{-\mathrm{BMDC}}$ co-cultured with $\mathrm{CD} 4{ }^{*} \mathrm{~T}$ cells isolated from mock infected mice. ${ }^{\S}$ compared to $\mathrm{Cm}$ infected miR-155 ${ }^{-} \mathrm{BMDC}$ co-cultured with $\mathrm{CD} 4^{+} \mathrm{T}$ cells isolated from mock infected mice. Results are representative of 2 independent experiments. $P<0.05$ using ANOVA with Bonferroni's Multiple Comparison Test. 
mice and was comparable to levels in Cm infected WT BMDC cocultured with $\mathrm{CD}^{+} \mathrm{T}$ cells from $\mathrm{Cm}$ infected mice (Figure 6a).

Overall, these data using mimics, inhibitors and in vivo depletion strategies strongly suggest that miRs 155 and -182 together compensate for the individual effect of each miR on production of IFN- $\gamma$ and co-regulate the production of IFN- $\gamma$ in co-cultures of $\mathrm{Cm}$ infected DC and $\mathrm{CD}^{+} \mathrm{T}$ cells (as shown summarized in Supplementary Table 2).

\section{DISCUSSION}

There is growing evidence that miRs contribute to critical processes including immune cell development/ function [13], reproductive biology [16, 36], and vaccination $[37,38]$. We have previously reported the potential of miRs to regulate immunity in the genital tract of $\mathrm{Cm}$ infected mice from days 6 and 12 post infection [11]. These time points of analyses were chosen as respective representatives of initial and subsequent stages of host immunity and genital $\mathrm{Cm}$ infection in the well-established murine model described by several laboratories including ours [3, 4, 7-10]. Additionally, we have reported that miR-214, selected from our initial report [11], specifically regulates $I C A M-1$ in the $\mathrm{Cm}$ infected genital tract, and contributes to causation of upper genital pathology in wild type and IL-17A deficient mice [18]. However, given that our initial reports [11] focused on the genital tract tissue and that the specific cell contributing to the miR responses was not investigated, we extended our hypothesis to investigate the role of immune cell specific miRs in the current study. This study provides insights on specific miRs from two key immune cell types involved in the interaction between innate and adaptive immunity post $\mathrm{Cm}$ infection. Although it is well established that following a genital infection with $\mathrm{Cm}$, DC are the principle cell populations that professionally present $\mathrm{Ag}$ to $\mathrm{CD}^{+} \mathrm{T}$ cells to mediate protective immunity, and were hence the choice of cells for this initial study, the role of miRs in other immune cell populations requires future investigation $[1,7,39,40]$. Importantly, this study underscores the growing importance of miRs as regulators/ modulators of host processes in Chlamydia biology [19, $21,23,41-43]$ at its naturally infecting sites including the lung, eye and the female reproductive tract-where the role of miRs in immune regulation in other models have been well documented [15, 44, 45]. Additionally, it extends our initial report on the role of miRs in modulating host immunity in the genital tract of Cm infected mice [11].

Identification of miRs in cultured DC infected with $\mathrm{Cm}$ revealed only 12/88 miRs probed being regulated compared to mock infected controls (Figure 1, Supplementary Table 1). Of these, the contribution of miR155 was investigated here for its well- established role in modulating host immunity $[30,31]$. Using inhibitors and mimics of miR-155, we established its contribution in activation of DC by regulation of MHC-II expression in $\mathrm{CD} 11 \mathrm{c}^{+} \mathrm{BMDC}$ (Figure 2). These observations are in agreement with the findings of Dunand-Sauthier et al., on the regulation of $\mathrm{MHC}-\mathrm{II}$ in miR-155 deficient mice [32]. Additionally, up-regulation of miR-155 in C57BL6 mice infected with $\mathrm{Cm}$ mutant strains as reported by Yeruva et al., and the recent report on the relationship of miR-155 and -184 in ocular Ct infection associated inflammation are indicative of the intrinsic contribution/ role of miR-155 in $\mathrm{Ct}$ infections [23, 46]. Importantly, we found that co-culture of miR-155 inhibitor and mimic transfected BMDC or miR-155/- BMDC with $\mathrm{CD}^{+} \mathrm{T}$ cells isolated at day 12 post infection from $\mathrm{Cm}$ infected mice resulted in significant modulation of Ag-specific IFN- $\gamma$ production (Figure 3b). We co-cultured BMDC with Ag-specific $\mathrm{CD}^{+} \mathrm{T}$ cells isolated specifically from day 12 post infection from $\mathrm{Cm}$ or mock infected mice as it is well established that the $\mathrm{CD} 4^{+} \mathrm{T}$ cells are (1), the primary source of Ag-specific IFN- $\gamma$ production [27]; (2), CD4 ${ }^{+} \mathrm{T}$ cells are the most important effector cell population that have the potential to provide protective responses against a subsequent infection [9] and; (3), adaptive immune responses are initiated around days 12-15 post infection in a well characterized 27-33 day murine genital infection model $[7,10]$. Increased levels of IFN- $\gamma$ production correlated with significant up-regulated expression of transcription factor $T b \times 21$ indicating clonal expansion of Th1 cells (data not shown). Interestingly, regulation of MHC-II by miR-155 inhibitor (Figure 2), and IFN- $\gamma$ production when these treated cells were co-cultured with Ag-specific CD4 ${ }^{+} \mathrm{T}$ cells (Figure 3 ) were not observed as co-related. However, given that Ag-priming and cognate binding is dependent on several factors including MHCII levels, we speculate that the probable mechanisms in the $\mathrm{T}$ cell component may exert its effect in contributing to IFN- $\gamma$ production. Additionally investigations into regulation of activation of APC (i.e., MHC-II) by miR-155 via pathways involving molecules such as c-Fos, SHIP1, SOCS-1 and cytokines, IL-12 and IL-6, are warranted for a better understanding of Ag-specific IFN- $\gamma$ production in Ct infections [32, 47, 48].

Our results also demonstrate the down-regulation of transcription factor $F O X O-1$, and up-regulation of its controlling microRNA, i.e., miR-182 [35], in $\mathrm{CD}^{+} \mathrm{T}$ cells isolated at day 12 post infection from $\mathrm{Cm}$ infected mice compared to mock infected animals (Figure 4). Importantly, miR-182 and its family member, miR-183 were significantly co-regulated in $\mathrm{CD}^{+} \mathrm{T}$ cells isolated from vaccinated mice protected at day 6 after a subsequent intravaginal $\mathrm{Cm}$ infection (Figure 4c, 4d). Collectively, these results suggest miR-182 may potentially be critically involved in initiation of adaptive immunity following $\mathrm{Cm}$ infection (isolated at day 12 post infection) and may also be involved in vaccine mediated protection (isolated at day 6 post infection in vaccinated mice). We have previously 
reported that miRs 182 and -183 are significantly modulated in the $\mathrm{Cm}$ infected genital tract, and are upregulated in the lower genital tract of $\mathrm{Cm}$ infected CD4 1- mice compared to the wild type [11]. Taken together, data from both studies suggest that the miR-182 family is involved in genital $\mathrm{Cm}$ infection, and has cell- and tissuespecific function in infected mice. Additionally, altered immune responses in miR-182 deficient mice [49], [50] highlights the importance of further investigating the role of $\mathrm{Cm}$-specific immune responses in this genetically deficient background. We thus employed a miR-182 depletion strategy to demonstrate the direct contribution of miR-182 to Ag-specific IFN- $\gamma$ production. To this end, miR-182 inhibitors were formulated in polymeric, PEI-based nanoparticles for in vivo delivery [51, 52]. In accordance with our previous findings [11], we observed a significant reduction in miR-182 expression in genital tracts (Figure 5c) or in $\mathrm{CD}^{+} \mathrm{T}$ cells (Figure $5 \mathrm{~d}$ ) isolated from miR-182 inhibitor treated mice compared to controltreated or mock treated mice post $\mathrm{Cm}$ infection. The significant reduction in Ag-specific IFN- $\gamma$ was associated with significant decrease in development of upper genital pathology in miR-182 inhibitor treated mice compared to $\mathrm{Cm}$ infected mice (Figure 5e). Additionally, comparable levels of bacterial shedding in miR-182 inhibitor treated and control groups of mice is in agreement with our previous report on the down-regulation of miR-182 in murine genital tracts following $\mathrm{Cm}$ infection or colonization within infected hosts [11]. Given that miR182 is down-regulated in $\mathrm{Cm}$ infected mice, the in vivo depletion regimen (Figure 5a) resulted in an environment that would aid $\mathrm{Cm}$ colonization in the genital tract [11]. Also, while the level of Ag-specific IFN- $\gamma$ production (Figure 5e) was significantly reduced in miR-182 depleted mice, the lack of a significant increase in bacterial shedding (Figure 5f, 5g) can be compared to previous findings on early to mid stage shedding in WT and IFN- $\gamma$ signaling deficient mice $[53,54]$, the contribution of other molecules/ immune cells altered in vivo to this end cannot be ruled out. Significant reduction in upper genital pathology and total cellular infiltrates in miR-182 inhibitor treated mice, compared to mock or scramble treated mice, following $\mathrm{Cm}$ infection (Figure 5h, 5i) were in accordance with previous reports on the reduced inflammatory cellular infiltrates contributing to reduced genital pathology [53, 55-58]. Additionally, a recent study by Ichiyama et al., establishes the role of miR-182-183-96 cluster in driving $\mathrm{Th}_{17}$ pathogenicity via inhibition of FOXO-1 $[59,60]$. The FOXO-1-miR cluster regulatory axis in this report adds to (1), our findings (Figure 4) and (2), the understanding of the mechanistic contribution of IL-17A (a member of the Th17 family) in chlamydial pathogenesis. We [18] and others [55] have reported that $i$. vag $\mathrm{Cm}$ infected IL-17A deficient mice compared to WT mice display significantly abrogated bacterial shedding kinetics and genital pathology. Additional studies using lineage specific mice will delineate the contribution of miR-182 cluster regulation of $T h_{1}$ and $T h_{17}$ specific host immunity and its relative effect on development of upper genital pathology following $\mathrm{Cm}$ infection [59].

We established a role for miR-182 in regulating IFN- $\gamma$ production in an Ag-specific manner (Figure 6). A significant increase in IFN- $\gamma$ production was observed when miR-155 mimic transfected BMDC was co-cultured with miR-182 mimic transfected $\mathrm{CD}^{+} \mathrm{T}$ cells isolated from $\mathrm{Cm}$ infected mice compared to mock infected BMDC (Figure 6a). These levels were comparable to untransfected conditions. This 'co-culture' combination of using miR mimics for both cell types provided a surrogate model to mimic the up-regulation of miRs 155 and -182 in $\mathrm{Cm}$ infected cells. Additionally, using a miR-155 BMDC: miR-182 depleted $\mathrm{CD}^{+} \mathrm{T}$ cell co-culture (Figure $6 a)$, we corroborated the interaction of the 2 miRs and the co-regulatory effect on IFN- $\gamma$ production (as summarized in Supplementary Table 2). Importantly, these findings were in agreement with in vivo observations on $\mathrm{DC}-\mathrm{CD} 4^{+}$ $\mathrm{T}$ cell interactions which lead to significantly increased IFN- $\gamma$ production and protective responses upon genital Cm infection [26, 27].

Overall, this study provides novel information on regulation of 'anti-Cm' immunity by cell type specific miRs. However, the current study lacks data on specific targets of miRs 155 and -182 in BMDC or $\mathrm{CD}^{+} \mathrm{T}$ cells, respectively. Given that (1), both miRs-155 and -182 were up-regulated following $\mathrm{Cm}$ infection (Figures 1, 4); (2), co-culture of unmanipulated $\mathrm{CD}^{+} \mathrm{T}$ cells with overexpressed miR-155 DCs (Figure 3), or unmanipulated DCs with over-expressed miR-182 $\mathrm{CD}^{+} \mathrm{T}$ cells (data not shown) respectively, lead to reduction in Ag-specific IFN- $\gamma$; (3), miR-182 was observed to be up-regulated in vaccinated mice protected against a subsequent $\mathrm{Cm}$ infection where protection may be mediated by production of Ag-specific IFN- $\gamma$ (Figure 4) and (4), miRs act by damping the target gene/ gene product, that additional investigation is warranted on IFN- $\gamma$ signaling specific genes and regulators whose function is altered by these two miRs and result in Ag-specific IFN- $\gamma$ (Figure 6) required for controlling $\mathrm{Cm}$ infection. Importantly, the availability of miR-155 and -182 deficient mice $[32,61]$, and the use of transfection strategies to determine miRmRNA targets [32] upon $\mathrm{Cm}$ infection will be key and aid in determining the specific targets of these miRs that regulate downstream IFN- $\gamma$ production.

This study establishes the specific contribution of two miRs in generation of anti-Ct immune responses and provides new information that can be beneficial for the rationale design of an effective anti-Ct vaccine. Moreover, given that (1), Ct is the leading cause of STIs globally [5], (2) a key mucosal pathogen in the female genital tract [62], and that (3), co-infections and the urogenital microbiome may be affected by and/ or influence Ct induced host immune responses [63-65], investigations on the role of 
miRs in regulating inherent host functions at the genital microenvironment are timely and essential for formulating paradigm shifting concepts.

\section{MATERIALS AND METHODS}

\section{Chlamydia muridarum stocks}

Seed stocks of Cm were propagated in HeLa 229 cells. At 24 h post infection, HeLa cells were mechanically disrupted, and following high speed centrifugation, bacterial pellets were purified on Renografin gradient as previously described [27].

\section{Mice}

All procedures were carried out in compliance with Institutional Animal Care and Use Committee (IACUC) guidelines. Female, 4-6 week old wild type C57BL/6 (WT) mice and miR-155/- were purchased from Jackson Laboratory.

\section{Intravaginal challenge}

In order to render the mice anestrous and more receptive to the genital infection, a single subcutaneous injection containing $2.5 \mathrm{mg}$ Depo progesterone (DepoProvera; Pharmacia \& Upjohn Co., NY, USA) was administered five days prior to infection. Mice were intravaginally infected with purified $\mathrm{Cm}$ diluted in $15 \mu \mathrm{L}$ sucrose/phosphate/glutamate (SPG) buffer at a final inoculating dose of $5 \times 10^{4}$ IFU [27]. For miR182 depletion studies, using a timeline (Figure 5a), mice were treated intraperitoneally (i.p) with $10 \mathrm{mg} / \mathrm{mouse} /$ time point scramble- and miR-182 inhibitors. Bacterial shedding and upper genital pathology was assessed as described previously [27]. At day 80 post infection, genital tracts were removed from all groups of mice, fixed in $10 \%$ neutral formalin, and embedded into paraffin blocks. Serial horizontal sections $(5 \mu \mathrm{m})$ were prepared and every tenth section ( $\sim 8-10$ sections per tissue) was stained using hematoxylin and eosin (H\&E). Stained sections were visualized using a Zeiss Axioskop 2 Plus research microscope and images were acquired using an Axiocam digital camera (Zeiss, Thornwood, NY). Representative sections stained with $H \& E$ were scored in a blinded fashion by a trained pathologist using a scoring scheme as described previously [66]. Results were expressed as mean \pm SEM of scores from all animals in a group ( $n$ $=10)$. From a subset of mice $(n=3) /$ treatment group genital tract (days $6,12,80$ ) and splenic $\mathrm{CD}^{+} \mathrm{T}$ cells (day 12) were collected and stored in $-80 \mathrm{o} C$ till further use. Genital tissue was ground using mortar and pestle and the crushed tissue was divided into 2 portions for isolating RNA (for miR PCR) and DNA (16s encoding gene PCR) respectively. Expression of miR-182 and -183 using miR-specific RT-PCR was performed as described below and bacterial burdens (days 6, 12, 80 for Chlamydia 16s encoding gene PCR from genital tract) were determined using primers and PCR parameters as described by Wooters et al [67].

\section{Vaccination studies}

For vaccination studies, mice were intranasally immunized with 500 IFU live $\mathrm{Cm}$ and rested for a month. Following intravaginal infection with $5 \times 10^{4} \mathrm{IFU} \mathrm{Cm}$, mice were swabbed at days 2, 4, and 6 for cervical-vaginal bacterial shedding. At day 6 post $\mathrm{Cm}$ infection, mice were euthanized for isolating splenocytes.

\section{Cell cultures}

\section{Bone marrow derived dendritic cells (BMDC)}

Female C57BL/6 mice ( $n=3-5$ / experiment) were euthanized and bone marrow was collected from the tibia and femur under aseptic conditions. BMDC were prepared as described previously with slight modifications [26]. At day 7 of culture, all cells were pooled and enriched using CD11c positive selection kit (Stem Cell Technologies, Vancouver). Following enrichment (purity $>85 \%$ by flow cytometry), BMDC were cultured in 96 well plates and treated with miR-155 mimic and/or inhibitor as described below.

\section{CD4 $^{+}$T-cells}

At day 12 post infection, mock or $\mathrm{Cm}$ infected mice were euthanized and spleens isolated. Single cells were prepared as described previously [26]. CD4 ${ }^{+} \mathrm{T}$-cells were purified (purity $>85-90 \%$ by flow cytometry) using a CD4 enrichment protocol per manufacturer's recommendation (StemCell). CD4+ T-cells were manipulated with miR-182 mimic prior to co-culture with treated BMDC.

\section{Co-culture}

At $24 \mathrm{~h}$ post $\mathrm{Cm}$ infection in treated BMDC, $\mathrm{CD}^{+}$ T-cells were over-layed at a BMDC: CD4 ratio of 1:2.5 (for miR-155 manipulation experiments), and 1:2 (for miR-155 and -182 treatment experiments). Co-cultured cells were incubated at $37^{\circ} \mathrm{C}$ for $72 \mathrm{~h}$. After $72 \mathrm{~h}$, cells were centrifuged at $1200 \mathrm{rpm}$ at $4^{\circ} \mathrm{C}$ for $10 \mathrm{~min}$, and the supernatant was collected and stored at $-80{ }^{\circ} \mathrm{C}$ for ELISA. 


\section{MicroRNA inhibitors formulation for in vivo depletion studies}

For miR-inhibitor delivery, polymeric nanoparticles based on polyethylenimine (PEI, vehicle) were employed. More specifically, PEI F25-LMW / inhibitor complexes was prepared as previously described for siRNA [51]. In brief, $5 \mathrm{mg}$ of the inhibitor mmu-miR-182-5p or the scrambled negative control oligonucleotide (IDT, Coralville, IA) were dissolved in $5 \mathrm{ml} \mathrm{HN}$ buffer (10 mM HEPES, $150 \mathrm{mM} \mathrm{NaCl}, \mathrm{pH}$ 7.4), yielding a $400 \mathrm{nM}$ stock solution. For complexation, $110 \mu \mathrm{l}$ of this stock solution were diluted in $761 \mu \mathrm{HN}$ buffer. In parallel, $825 \mu \mathrm{g}$ PEI F25-LMW [52] was diluted to a final volume of $780 \mu \mathrm{l}$ in $\mathrm{HN}$ buffer. After incubation for $10 \mathrm{~min}$, the PEI solution was added to the inhibitor solution, vortexed and incubated for $30 \mathrm{~min}$ at room temperature. For the complexation of smaller amounts, $40 \mu \mathrm{g}$ oligonucleotide in $242 \mu 1 \mathrm{HN}$ buffer was complexed with $300 \mu \mathrm{g}$ PEI F25LMW in $320 \mu \mathrm{HN}$ buffer in the same manner. Complexes were stored in $-80^{\circ} \mathrm{C}$ prior to use.

\section{In vitro transfection of microRNA mimics and inhibitors}

BMDC and $\mathrm{CD} 4^{+}$T-cells were seeded at a density of $2 \times 10^{5}$ or $5 \times 10^{5}$ respectively, per well. MiR-155 or -182 agomiR (MiScript miRNA Mimics, Qiagen, Valencia, $\mathrm{CA}$ ), and antagomiR (MiScript miRNA Inhibitor) were transfected using Attractene as transfection reagent at a concentration of $20 \mu \mathrm{M}$ by fast forward transfection per manufacturer's recommendation (Qiagen). Transfection was carried out for $24 \mathrm{~h}$ (BMDC), and $18 \mathrm{~h}\left(\mathrm{CD} 4^{+} \mathrm{T}\right.$-cells) followed by $\mathrm{Cm}$ infection (BMDC) or co-culture with infected BMDC (CD4 ${ }^{+}$T-cells). Prior to infection or coculture, efficiency of transfection or in vivo depletion and cell viability was determined by Real Time PCR and MTS assay (Promega, Madison, WI), respectively, (data not shown).

\section{RNA extraction and quantitative reverse transcriptase (qRT)-PCR}

Total RNA was extracted from BMDC and splenic $\mathrm{CD}^{+} \mathrm{T}$-cells at $24 \mathrm{~h}$ post infection or 12 days post infection, respectively. For vaccination studies, splenic $\mathrm{CD}^{+}{ }^{+} \mathrm{T}$-cells were isolated 6 days post infection. RNA was obtained using a miRNeasy RNA extraction Kit (Qiagen) according to the manufacturer's instructions. Total RNA was assessed using a Nanodrop Spectrophotometer (ThermoScientific, Asheville, NC). RNA samples exhibiting $\mathrm{A}_{260 / 280} \cong 2.0$ and $\mathrm{A}_{260 / 230} \cong 1.8$ were converted to cDNA using a RT2 First Strand cDNA Kit (Qiagen) according to the manufacturer's instructions.
RNA $(1 \mu \mathrm{g})$ was used in all miR PCR amplifications, and were performed using custom designed miScript miR-155, -182 , and -183 primers (Qiagen) according to the manufacturer's instructions. For FOXO-1, Tbx21, FoxP3, GATA3, and RoR $\gamma$ expression, RNA $(1 \mu \mathrm{g})$ was converted to cDNA using an iScript ${ }^{\mathrm{TM}}$ cDNA Synthesis Kit followed by real time PCR using the SsoAdvanced ${ }^{\mathrm{TM}}$ Universal SYBR ${ }^{\circledR}$ Green Supermix (Bio-Rad, Hercule, $\mathrm{CA}$ ) with gene specific primer pairs $\left(\right.$ PrimePCR ${ }^{\mathrm{TM}}$ SYBR ${ }^{\circledR}$ Green Assay, BioRad, UniqueAssay ID: FOXO1 qMmuCID0016391) on a CFX 96 instrument (BioRad). All miR expression analyses were normalized to housekeeping miRs RNU6-2_1 and SNORD68 expression values (for BMDC experiments) and SNORD68 and 85 (for $\mathrm{CD}^{+}{ }^{+} \mathrm{T}$-cell experiments). All gene expression analyses were normalized to housekeeping genes GAPDH. Data are represented as fold-change relative to mock control as indicated in the Results and Figure legends using the comparative cycle threshold method [11].

\section{Flow cytometry}

Cells were stained with fluorochrome-conjugated CD-11c, and MHC-II labeled antibodies (Biolegend, San Diego, CA), and FACS analysis was performed using a LSR II instrument (BD Biosciences) [27].

\section{ELISA}

Supernatants from 'co-culture' wells were analyzed for IFN- $\gamma$ production using BD OptELISA kits (BD Pharmingen, NJ, USA) as previously described [26]. Cells were stimulated with media, BSA, live Cm (or UV$\mathrm{Cm}$, mentioned in figure legend) and non related antigens (Myelin Oligodendrocyte Glycoprotein $M O G_{35-55}$ ).

\section{ELISPOT}

At day 6 post $\mathrm{Cm}$ infection, splenocytes were isolated from all groups of mice in vaccination studies, and single cell suspensions made as previously described [26]. IFN- $\gamma$ ELISPOT was performed on 96-well MultiScreen HTS filtration plates (Millipore), and results captured on an ImmunoSpot Series 3 analyzer (Cellular Technology, Ltd., $\mathrm{OH}$ ) as per specifications [68].

\section{Statistical analyses}

MiR analysis was performed using $\mathrm{RT}^{2}$ Profiler PCR Array Data Analysis (version 3.5, Qiagen). All experimental results were calculated as the mean $\pm \mathrm{SE}$ of 2-5 independent experiments $(n=3-5)$ indicated in respective figure legends. Student's $t$-test was used for comparison between two groups. ANOVA with post-hoc 
multiple comparison test was used for multiple groups. Kruskall-Wallis test was used for comparing bacterial shedding profiles. Differences were considered statistically significant if $\mathrm{P}$ values were $<0.05$. All statistical analyses were conducted using the GraphPad Prism 5 software package (La Jolla, CA).

\section{ACKNOWLEDGMENTS}

This work was supported by National Institutes of Health Grant (1RO1AI074860) and the Army Research Office, Department of Defense contract No. W911NF-11-1-0136.

\section{DISCLOSURE}

The authors declare that they have no competing interests.

\section{Author contributions}

RG, TA, JK, carried out all experiments including bacterial inoculum preparation, cell line experiments, real-time microRNA and DNA PCR amplification, flow cytometry, shedding and pathology experiments. GPL and $\mathrm{KC}$ assisted in ELISPOT and H\&E staining experiments. $\mathrm{SH}$ and AA formulation the in vivo depletion injections. RG and BPA conceptualized the project and analyzed the data. RG, JJY, NG, JPC, AA, LKC, BPA drafted and edited the manuscript. All authors have read and approved the final manuscript.

\section{Editorial note}

This paper has been accepted based in part on peerreview conducted by another journal and the authors' response and revisions as well as expedited peer-review in Oncotarget.

\section{REFERENCES}

1. Darville T and Hiltke TJ. Pathogenesis of genital tract disease due to Chlamydia trachomatis. J Infect Dis. 2010; 201 Suppl 2:S114-125.

2. Perry LL, Feilzer $\mathrm{K}$ and Caldwell HD. Immunity to Chlamydia trachomatis is mediated by $\mathrm{T}$ helper 1 cells through IFN-gamma-dependent and -independent pathways. Journal of immunology. 1997; 158(7):3344-3352.

3. Hafner L, Beagley K and Timms P. Chlamydia trachomatis infection: host immune responses and potential vaccines. Mucosal immunology. 2008; 1(2):116-130.

4. Brunham RC and Rey-Ladino J. Immunology of Chlamydia infection: implications for a Chlamydia trachomatis vaccine. Nature reviews Immunology. 2005; 5(2):149-161.
5. Centers for Disease Control and Prevention. Incidence, Prevalence, and Cost of Sexually Transmitted Infections in the United States (http://www.cdc.gov/std/stats/STIEstimates-Fact-Sheet-Feb-2013.pdf) 2013.

6. Gottlieb SL, Berman SM and Low N. Screening and treatment to prevent sequelae in women with Chlamydia trachomatis genital infection: how much do we know? J Infect Dis. 2010; 201 Suppl 2:S156-167.

7. Farris CM and Morrison RP. Vaccination against Chlamydia genital infection utilizing the murine C. muridarum model. Infection and immunity. 2011; 79(3):986-996.

8. Igietseme JU, Eko FO and Black CM. Chlamydia vaccines: recent developments and the role of adjuvants in future formulations. Expert review of vaccines. 2011; 10(11):1585-1596.

9. Nogueira CV, Zhang X, Giovannone N, Sennott EL and Starnbach MN. Protective Immunity against Chlamydia trachomatis Can Engage Both CD4+ and CD8+ T Cells and Bridge the Respiratory and Genital Mucosae. Journal of immunology. 2015; 194(5):2319-2329.

10. Murthy AK, Guentzel MN, Zhong G and Arulanandam BP. Chlamydial protease-like activity factor-insights into immunity and vaccine development. Journal of reproductive immunology. 2009; 83(1-2):179-184.

11. Gupta R, Arkatkar T, Yu JJ, Wali S, Haskins WE, Chambers JP, Murthy AK, Bakar SA, Guentzel MN and Arulanandam BP. Chlamydia muridarum infection associated host MicroRNAs in the murine genital tract and contribution to generation of host immune response. American journal of reproductive immunology. 2015; 73(2):126-140.

12. Lu LF and Liston A. MicroRNA in the immune system, microRNA as an immune system. Immunology. 2009; 127(3):291-298.

13. Baumjohann D, Kageyama R, Clingan JM, Morar MM, Patel S, de Kouchkovsky D, Bannard O, Bluestone JA, Matloubian M, Ansel KM and Jeker LT. The microRNA cluster miR-17 approximately 92 promotes TFH cell differentiation and represses subset-inappropriate gene expression. Nat Immunol. 2013; 14(8):840-848.

14. Kroesen BJ, Teteloshvili N, Smigielska-Czepiel K, Brouwer E, Boots AM, van den Berg A and Kluiver J. ImmunomiRs: Critical regulators of T-cell development, function and ageing. Immunology. 2014.

15. Nothnick WB. The role of micro-RNAs in the female reproductive tract. Reproduction. 2012; 143(5):559-576.

16. Christenson LK. MicroRNA control of ovarian function. Anim Reprod. 2010; 7(3):129-133.

17. Cubillos-Ruiz JR, Baird JR, Tesone AJ, Rutkowski MR, Scarlett UK, Camposeco-Jacobs AL, Anadon-Arnillas J, Harwood NM, Korc M, Fiering SN, Sempere LF and Conejo-Garcia JR. Reprogramming tumor-associated dendritic cells in vivo using miRNA mimetics triggers protective immunity against ovarian cancer. Cancer research. 2012; 72(7):1683-1693. 
18. Arkatkar T, Gupta R, Li W, Yu JJ, Wali S, Neal Guentzel M, Chambers JP, Christenson LK and Arulanandam BP. Murine MicroRNA-214 regulates intracellular adhesion molecule (ICAM1) gene expression in genital Chlamydia muridarum infection. Immunology. 2015; 145(4):534-542.

19. Furuse Y, Finethy R, Saka HA, Xet-Mull AM, Sisk DM, Smith KL, Lee S, Coers J, Valdivia RH, Tobin DM and Cullen BR. Search for microRNAs expressed by intracellular bacterial pathogens in infected mammalian cells. PLoS One. 2014; 9(9):e106434.

20. Igietseme JU, Omosun Y, Stuchlik O, Reed MS, Partin J, He Q, Joseph K, Ellerson D, Bollweg B, George Z, Eko FO, Bandea C, Liu H, et al. Role of Epithelial-Mesenchyme Transition in Chlamydia Pathogenesis. PLoS One. 2015; 10(12):e0145198.

21. Igietseme JU, Omosun Y, Partin J, Goldstein J, He Q, Joseph K, Ellerson D, Ansari U, Eko FO, Bandea C, Zhong $\mathrm{G}$ and Black CM. Prevention of Chlamydia-induced infertility by inhibition of local caspase activity. J Infect Dis. 2013; 207(7):1095-1104.

22. Wang W, Stassen FR, Surcel HM, Ohman H, Tiitinen A, Paavonen J, de Vries HJ, Heijmans R, Pleijster J, Morre $\mathrm{SA}$ and Ouburg S. Analyses of polymorphisms in the inflammasome-associated NLRP3 and miRNA-146A genes in the susceptibility to and tubal pathology of Chlamydia trachomatis infection. Drugs Today (Barc). 2009; 45 Suppl B:95-103.

23. Yeruva L, Myers GS, Spencer N, Creasy HH, Adams NE, Maurelli AT, McChesney GR, Cleves MA, Ravel J, Bowlin A and Rank RG. Early microRNA expression profile as a prognostic biomarker for the development of pelvic inflammatory disease in a mouse model of chlamydial genital infection. MBio. 2014; 5(3):e01241-01214.

24. Darville T, Andrews CW, Jr., Sikes JD, Fraley PL and Rank RG. Early local cytokine profiles in strains of mice with different outcomes from chlamydial genital tract infection. Infection and immunity. 2001; 69(6):3556-3561.

25. Eko FO, Mania-Pramanik J, Pais R, Pan Q, Okenu DM, Johnson A, Ibegbu C, He C, He Q, Russell R, Black CM and Igietseme JU. Vibrio cholerae ghosts (VCG) exert immunomodulatory effect on dendritic cells for enhanced antigen presentation and induction of protective immunity. BMC immunology. 2014; 15(1):584.

26. Li W, Murthy AK, Chaganty BK, Guentzel MN, Seshu J, Chambers JP, Zhong G and Arulanandam BP. Immunization with dendritic cells pulsed ex vivo with recombinant chlamydial protease-like activity factor induces protective immunity against genital Chlamydia muridarum challenge. Frontiers in immunology. 2011; 2:73.

27. Li W, Murthy AK, Guentzel MN, Seshu J, Forsthuber TG, Zhong G and Arulanandam BP. Antigen-specific CD4+ $\mathrm{T}$ cells produce sufficient IFN-gamma to mediate robust protective immunity against genital Chlamydia muridarum infection. Journal of immunology. 2008; 180(5):3375-3382.

28. Lind EF and Ohashi PS. Mir-155, a central modulator of
T-cell responses. European journal of immunology. 2014; 44(1):11-15.

29. Mashima R. Physiological roles of miR-155. Immunology. 2015.

30. Yao R, Ma YL, Liang W, Li HH, Ma ZJ, Yu X and Liao YH. MicroRNA-155 modulates Treg and Th17 cells differentiation and Th17 cell function by targeting SOCS1. PLoS One. 2012; 7(10):e46082.

31. Turner ML, Schnorfeil FM and Brocker T. MicroRNAs regulate dendritic cell differentiation and function. Journal of immunology. 2011; 187(8):3911-3917.

32. Dunand-Sauthier I, Santiago-Raber ML, Capponi L, Vejnar CE, Schaad O, Irla M, Seguin-Estevez Q, Descombes P, Zdobnov EM, Acha-Orbea H and Reith W. Silencing of c-Fos expression by microRNA-155 is critical for dendritic cell maturation and function. Blood. 2011; 117(17):44904500 .

33. Stahl M, Dijkers PF, Kops GJ, Lens SM, Coffer PJ, Burgering BM and Medema RH. The forkhead transcription factor FoxO regulates transcription of p27Kip1 and Bim in response to IL-2. Journal of immunology. 2002; 168(10):5024-5031.

34. Kim KM, Park SJ, Jung SH, Kim EJ, Jogeswar G, Ajita $\mathrm{J}$, Rhee Y, Kim CH and Lim SK. miR-182 is a negative regulator of osteoblast proliferation, differentiation, and skeletogenesis through targeting FoxO1. Journal of bone and mineral research. 2012; 27(8):1669-1679.

35. Stittrich AB, Haftmann C, Sgouroudis E, Kuhl AA, Hegazy AN, Panse I, Riedel R, Flossdorf M, Dong J, Fuhrmann F, Heinz GA, Fang Z, Li N, et al. The microRNA miR-182 is induced by IL-2 and promotes clonal expansion of activated helper T lymphocytes. Nat Immunol. 2010; 11(11):10571062.

36. McGinnis LK, Luense LJ and Christenson LK. MicroRNA in Ovarian Biology and Disease. Cold Spring Harbor perspectives in medicine. 2015; 5(9):a022962.

37. Holmstrom K, Pedersen AW, Claesson MH, Zocca MB and Jensen SS. Identification of a microRNA signature in dendritic cell vaccines for cancer immunotherapy. Human immunology. 2010; 71(1):67-73.

38. Langlois RA, Albrecht RA, Kimble B, Sutton T, Shapiro JS, Finch C, Angel M, Chua MA, Gonzalez-Reiche AS, Xu K, Perez D, Garcia-Sastre A and tenOever BR. MicroRNAbased strategy to mitigate the risk of gain-of-function influenza studies. Nature biotechnology. 2013; 31(9):844847.

39. McSorley SJ. The Role of Non-Cognate T Cell Stimulation during Intracellular Bacterial Infection. Frontiers in immunology. 2014; 5:319.

40. Marks E, Verolin M, Stensson A and Lycke N. Differential CD28 and inducible costimulatory molecule signaling requirements for protective $\mathrm{CD} 4+\mathrm{T}$-cell-mediated immunity against genital tract Chlamydia trachomatis infection. Infection and immunity. 2007; 75(9):4638-4647. 
41. Zhao GJ, Mo ZC, Tang SL, Ouyang XP, He PP, Lv YC, Yao F, Tan YL, Xie W, Shi JF, Wang Y, Zhang M, Liu D, et al. Chlamydia pneumoniae negatively regulates ABCA1 expression via TLR2-Nuclear factor-kappa B and miR33 pathways in THP-1 macrophage-derived foam cells. Atherosclerosis. 2014; 235(2):519-525.

42. Derrick T, Roberts C, Rajasekhar M, Burr SE, Joof H, Makalo P, Bailey RL, Mabey DC, Burton MJ and Holland MJ. Conjunctival MicroRNA expression in inflammatory trachomatous scarring. PLoS neglected tropical diseases. 2013; 7(3):e2117.

43. Kim RY, Horvat JC, Starkey MR, Pinkerton JW, Starkey MR, Essilfie AT, Jemma RM, Nair P. M., G. HN, Jones B, Haw TJ, Sunkara KP, Nguyen TH, et al. MicroRNA-21 drives severe, steroid-insensitive experimental asthma by amplifying PI3K-mediated suppression of HDAC2 American journal of respiratory cell and molecular biology. 2016; doi:10.1016/j.jaci.2016.04.038.

44. Ishida W, Fukuda K, Higuchi T, Kajisako M, Sakamoto S and Fukushima A. Dynamic changes of microRNAs in the eye during the development of experimental autoimmune uveoretinitis. Investigative ophthalmology \& visual science. 2011; 52(1):611-617.

45. Foster PS, Plank M, Collison A, Tay HL, Kaiko GE, Li J, Johnston SL, Hansbro PM, Kumar RK, Yang M and Mattes $\mathrm{J}$. The emerging role of microRNAs in regulating immune and inflammatory responses in the lung. Immunological reviews. 2013; 253(1):198-215.

46. Derrick T, Last AR, Burr SE, Roberts CH, Nabicassa M, Cassama E, Bailey RL, Mabey DC, Burton MJ and Holland MJ. Inverse relationship between microRNA-155 and -184 expression with increasing conjunctival inflammation during ocular Chlamydia trachomatis infection. BMC infectious diseases. 2016; 16(1):60.

47. Smyth LA, Boardman DA, Tung SL, Lechler R and Lombardi G. MicroRNAs affect dendritic cell function and phenotype. Immunology. 2015; 144(2):197-205.

48. Ma YL, Ma ZJ, Wang M, Liao MY, Yao R and Liao YH. MicroRNA-155 induces differentiation of RAW264.7 cells into dendritic-like cells. International journal of clinical and experimental pathology. 2015; 8(11):14050-14062.

49. Pucella JN, Yen WF, Kim MV, van der Veeken J, Socci ND, Naito Y, Li MO, Iwai N and Chaudhuri J. miR-182 Is Largely Dispensable for Adaptive Immunity: Lack of Correlation between Expression and Function. Journal of immunology. 2015; 194(6):2635-2642.

50. Li YF, Ou X, Xu S, Jin ZB, Iwai N and Lam KP. Loss of miR-182 affects B-cell extrafollicular antibody response. Immunology. 2016; 148(2):140-149.

51. Hobel S, Koburger I, John M, Czubayko F, Hadwiger P, Vornlocher HP and Aigner A. Polyethylenimine/ small interfering RNA-mediated knockdown of vascular endothelial growth factor in vivo exerts anti-tumor effects synergistically with Bevacizumab. The journal of gene medicine. 2010; 12(3):287-300.
52. Werth S, Urban-Klein B, Dai L, Hobel S, Grzelinski M, Bakowsky U, Czubayko F and Aigner A. A low molecular weight fraction of polyethylenimine (PEI) displays increased transfection efficiency of DNA and siRNA in fresh or lyophilized complexes. Journal of controlled release. 2006; 112(2):257-270.

53. Murthy AK, Chambers JP, Meier PA, Zhong G and Arulanandam BP. Intranasal vaccination with a secreted chlamydial protein enhances resolution of genital Chlamydia muridarum infection, protects against oviduct pathology, and is highly dependent upon endogenous gamma interferon production. Infection and immunity. 2007; 75(2):666-676.

54. Cotter TW, Ramsey KH, Miranpuri GS, Poulsen CE and Byrne GI. Dissemination of Chlamydia trachomatis chronic genital tract infection in gamma interferon gene knockout mice. Infection and immunity. 1997; 65(6):2145-2152.

55. Andrew DW, Cochrane M, Schripsema JH, Ramsey KH, Dando SJ, O'Meara CP, Timms P and Beagley KW. The duration of Chlamydia muridarum genital tract infection and associated chronic pathological changes are reduced in IL-17 knockout mice but protection is not increased further by immunization. PLoS One. 2013; 8(9):e76664.

56. Yang Z, Conrad T, Zhou Z, Chen J, Dutow P, Klos A and Zhong G. Complement factor C5 but not C3 contributes significantly to hydrosalpinx development in mice infected with Chlamydia muridarum. Infection and immunity. 2014; 82(8):3154-3163.

57. Nagarajan UM, Sikes JD, Yeruva L and Prantner D. Significant role of IL-1 signaling, but limited role of inflammasome activation, in oviduct pathology during Chlamydia muridarum genital infection. Journal of immunology. 2012; 188(6):2866-2875.

58. Lee HY, Schripsema JH, Sigar IM, Murray CM, Lacy SR and Ramsey KH. A link between neutrophils and chronic disease manifestations of Chlamydia muridarum urogenital infection of mice. FEMS immunology and medical microbiology. 2010; 59(1):108-116.

59. Ichiyama K, Gonzalez-Martin A, Kim BS, Jin HY, Jin W, Xu W, Sabouri-Ghomi M, Xu S, Zheng P, Xiao C and Dong C. The MicroRNA-183-96-182 Cluster Promotes T Helper 17 Cell Pathogenicity by Negatively Regulating Transcription Factor Foxo1 Expression. Immunity. 2016; 44(6):1284-1298.

60. Kanellopoulou $\mathrm{C}$ and Muljo SA. Fine-Tuning Th17 Cells: To Be or Not To Be Pathogenic? Immunity. 2016; 44(6):1241-1243.

61. Jin ZB, Hirokawa G, Gui L, Takahashi R, Osakada F, Hiura Y, Takahashi M, Yasuhara $\mathrm{O}$ and Iwai N. Targeted deletion of miR-182, an abundant retinal microRNA. Molecular vision. 2009; 15:523-533.

62. Hafner LM, Cunningham K and Beagley KW. Ovarian steroid hormones: effects on immune responses and Chlamydia trachomatis infections of the female genital tract. Mucosal immunology. 2013; 6(5):859-875. 
63. Brotman RM, Ravel J, Bavoil PM, Gravitt PE and Ghanem KG. Microbiome, sex hormones, and immune responses in the reproductive tract: challenges for vaccine development against sexually transmitted infections. Vaccine. 2014; 32(14):1543-1552.

64. Gajer P, Brotman RM, Bai G, Sakamoto J, Schutte UM, Zhong X, Koenig SS, Fu L, Ma ZS, Zhou X, Abdo Z, Forney LJ and Ravel J. Temporal dynamics of the human vaginal microbiota. Science translational medicine. 2012; 4(132):132ra152.

65. Ravel J, Gajer P, Abdo Z, Schneider GM, Koenig SS, McCulle SL, Karlebach S, Gorle R, Russell J, Tacket CO, Brotman RM, Davis CC, Ault K, et al. Vaginal microbiome of reproductive-age women. Proceedings of the National Academy of Sciences of the United States of America. 2011; 108 Suppl 1:4680-4687.
66. Murphey C, Murthy AK, Meier PA, Neal Guentzel M, Zhong G and Arulanandam BP. The protective efficacy of chlamydial protease-like activity factor vaccination is dependent upon CD4+ T cells. Cellular immunology. 2006; 242(2):110-117.

67. Wooters MA, Kaufhold RM, Field JA, Indrawati L, Heinrichs JH and Smith JG. A real-time quantitative polymerase chain reaction assay for the detection of Chlamydia in the mouse genital tract model. Diagnostic microbiology and infectious disease. 2009; 63(2):140-147.

68. Li W, Murthy AK, Guentzel MN, Chambers JP, Forsthuber TG, Seshu J, Zhong G and Arulanandam BP. Immunization with a combination of integral chlamydial antigens and a defined secreted protein induces robust immunity against genital chlamydial challenge. Infection and immunity. 2010; 78(9):3942-3949. 